\title{
The rise and fall of Late Devonian (Frasnian) trilobites from Belgium: taxonomy, biostratigraphy and events
}

\author{
Allart P. VAN VIERSEN ${ }^{1 *} \&$ Willy VANHERLE 2
}

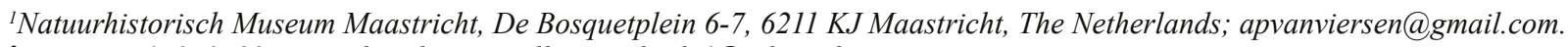
²Bosstraat 173, 3582 Koersel, Belgium; willem.vanherle1@telenet.be.

*corresponding author.

\begin{abstract}
Trilobites are recorded from Frasnian strata in Belgium on the basis of old museum collections and contemporary fieldwork. Of the four third-order Transgressive-Regressive (T-R) cycles recognised here in the latest Givetian to late Frasnian, the last three are each associated with a version of a largely coherent, acastid-scutelluid dominated trilobite fauna. Accents of this "base" fauna encompassed probably primarily allochthonous elements. The timing and effects of the late Frasnian Kellwasser Event in Belgium differ according to fossil group and their position along the ramp. The new data from this study are suggestive of distinct extinction patterns for the trilobite associations of the reefal environments and lateral facies. No evidence was identified for a direct impact of the Kellwasser levels on the Belgian trilobite fauna, although not a single trilobite is known with certainty from strata above the base of the Lower Kellwasser level. Comparisons to trilobite faunas from other countries are suggestive of open, shallow-water migration routes between southern Laurussia and peri-Gondwana during most of the Frasnian. New taxa are Bradocryphaeus echinatus sp. nov., Magreanops renateae gen. \& sp. nov. (both Moulin Liénaux Formation), Bradocryphaeus laomedeia sp. nov., Bradocryphaeus neptuni hottonensis ssp. nov., Cyphaspis koimeterionensis sp. nov. (all Grands Breux Formation), Magreanops monachus gen. \& sp. nov., Quadratispina excelsa sp. nov. (both Bovesse Formation) and Pterocoryphe platymarginata sp. nov. (Champ Broquet Formation). Magreanops gen. nov. represents the first and only known big-eyed phacopid from Frasnian strata worldwide, breaching the established latest Givetian to late Famennian gap of this group.
\end{abstract}

KEYWORDS: Trilobites, systematic palaeontology, palaeoecology, palaeobiogeography, extinctions.

\section{Introduction}

The Frasnian was a period of recurrent global eustatic perturbations that had already commenced in the Middle Devonian and led to major faunal crises. Frasnian trilobites, encompassing exclusively benthic and endobenthic inhabitants of the continental shelf, suffered consecutive blows from the worldwide "drowning" of reef ecosystems and a decline of the shallow water environments to which they were confined (Feist, 1991, 1995). The latest Frasnian Kellwasser Event, though not by itself responsible for the demise of Frasnian trilobites, was the "coup de grâce" for many families. This event and its effects on trilobites have been the focus of investigations at various sections located in Germany, France, Morocco and NW Australia, among other countries (e.g. Becker et al., 1989; Feist \& Schindler, 1994; Feist, 2002; McNamara \& Feist, 2016).

Frasnian trilobites from Belgium were described mainly in the monograph on Late Devonian trilobites of Richter \& Richter (1926) and in van Viersen \& Bignon (2011) and van Viersen \& Prescher (2011). Bignon \& Crônier (2015) analysed faunal dynamics of Devonian trilobites from Belgium and northern France and recognised two poorly diversified associations in the Frasnian: the Scutellum-Goldius association which they considered to be restricted to reef environments, and the Bradocryphaeus association (Bradocryphaeus, Otarion, Heliopyge) of Crônier \& van Viersen (2007) which occurs in lateral shales and limestones below fair-weather wave base.

The authors of the present note have made numerous excursions to Frasnian trilobite-bearing strata in Belgium over the past years. Additionally, one of us (AV) has examined the old Maillieux collections (see, e.g. Richter \& Richter, 1926; Maillieux, 1927, 1940) kept by the Institut royal des Sciences naturelles de Belgique (IRSNB). Here we report newly discovered Frasnian trilobites from Belgium including palaeogeographically significant taxa that were not previously known to occur here. The selected specimens from museum and recent field collections enable a first attempt at assessing the rise and fall of the Frasnian trilobite fauna concomitant with the rapidly changing palaeoenvironment.

\section{Localities}

\subsection{Depositional areas}

Frasnian rocks crop out in Belgium along the southern and northern flanks of both the Dinant Synclinorium and the Namur Basin, in the Philippeville Anticlinorium and in the Vesdre Nappe. Da Silva \& Boulvain (2004) distinguished three main depositional areas (Fig. 1):

1) Southern border of the Dinant Synclinorium or "southern belt": the distalmost environment, comprising carbonate mounds and lateral shales and limestones. Most contemporary fossil localities are contained within this belt and consequently, this area is currently the main source of Frasnian trilobite material from Belgium.

2) The Philippeville Anticlinorium or "intermediate belt": shales and limestones (Pont de la Folle Formation) followed by limestones comprising open-marine facies and biostromes (Philippeville Formation).

3) Northern border of the Dinant Synclinorium-Namur Basin, or "northern belt": the northern and southern flanks of the Namur Basin, though not strictly belonging to the same geological structure (Delmer, 2004; Coen-Aubert, 2015), encompass proximal limestones and an alternation of biostromes and lagoonal facies.

In the type area of the Frasnian on the southern border of the Dinant Synclinorium, the transgressive shales of the basal Frasnian Nismes Formation are succeeded by the Moulin Liénaux and Grands Breux formations, each of which represents a major T-R cycle (cycles 2 and 3 of Gouwy \& Bultynck, 2000). Both formations started as a basal calcareous ramp (Bieumont and Chalon members) whereas a stable carbonate factory enabled the offshore development of large carbonate build-ups (Arche and Lion members) more than $150 \mathrm{~m}$ thick and $1 \mathrm{~km}$ in diameter (Boulvain, 2007; Boulvain et al., 2011). These mounds, as they are referred to herein, have been subject to many palaeontological and sedimentological studies and more recently interpreted as atolls. Boulvain et al. (2005) described how both members started as carbonate build-ups in the course of a transgression, followed by a sea-level stillstand. During the subsequent period of low sealevel, reef growth was restricted to the rim of the build-up. The atoll crown then developed during a new transgressive phase. The presence of shallow-water facies within the crown suggests that 


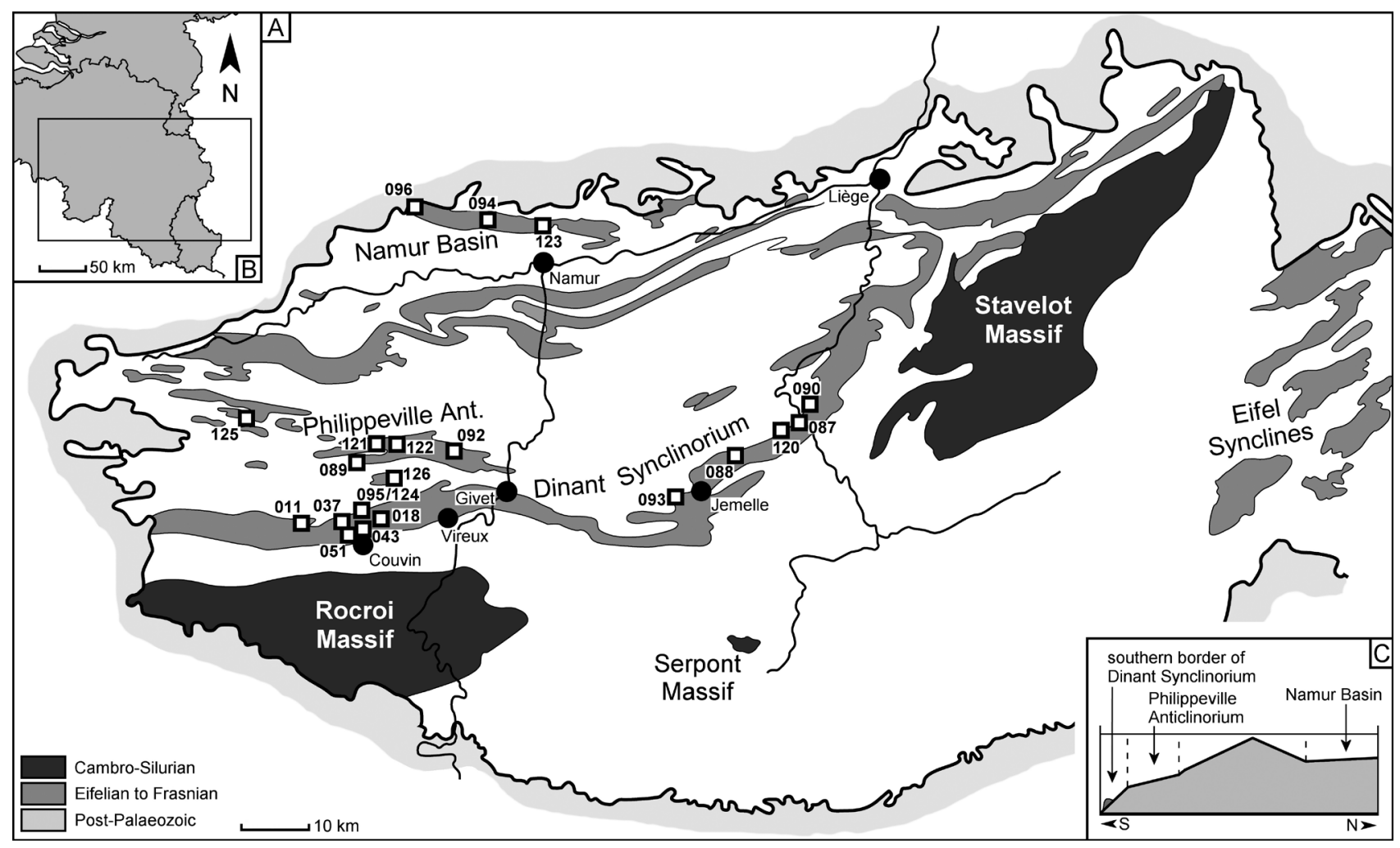

Figure 1. A. Geological map of the Ardennes (Belgium, northern France) with trilobite-bearing localities indicated. B. Inset map showing geographical position of the geological map. C. North-South transect of the Belgian platform during the Frasnian showing the three main depositional areas.

reef growth was able to keep up with sea-level rise. Eventually reef growth lost this contest as the mounds were 'drowned' and buried through clay deposition (shaly Ermitage and Boussuen-Fagne members) (= events 3 and 7 of Da Silva et al., 2010). However, Mottequin \& Poty (2015) argued that the shallow-water limestones and erosion-transgressive surface at the top of the Lion mound, disconformably overlain by the argillaceous Boussuen-Fagne Member in Frasnes, suggest a major sea-level drop instead. They regarded this regression as being responsible for the termination of the Lion mounds and a major disruption of Frasnian carbonate production. The late Frasnian Petit-Mont mounds of the Champ Broquet Formation are principally different from their middle Frasnian predecessors in having a limited lateral extension that was caused by the more drastically changing sea and oxygen levels leading to the relative instability of the carbonate factory (Boulvain, 2007). The demise of this last mound level was caused by another sea-level drop (Mottequin \& Poty, 2015).

\subsection{Contemporary localities}

Extensive quarry works, natural outcrops and road or railway sections in Belgian Frasnian strata have been known for many decades, providing excellent opportunities for scientific studies. Some of these places continue to serve as suitable outcrops for fossil collecting at present. They are frequented by collectors for their brachiopods, crinoids, goniatites, corals and trilobites, among other groups. We provide a list of selected trilobiteyielding sections below. Systematic palaeontology of the mentioned trilobites is dealt with in chapter 4.

Loc011, Lompret, Lompret Quarry just northeast of the village Lompret (Fig. 1). Outcrops in the southern part of the quarry and around the entrance belong to the Bieumont Member of the Grands Breux Formation (Humblet \& Boulvain, 2000); trilobites (Bradocryphaeus) are locally numerous there but poorly preserved. The Boussu-en-Fagne Member is exposed in the centre of the section; trilobites (Bradocryphaeus neptuni neptuni van Viersen \& Bignon, 2011, Bradocryphaeus cf. laomedeia sp. nov. and Cyphaspis sp. E) were collected by S. Goolaerts and F. Lerouge from shales and calcareous nodules enclosed within these shales, along with a common species of the brachiopod Corbicularia. A mound level is being mined in the northern part of the section. This structure is of Petit-Mont type according to the revised geological map (Barchy \& Marion, 1999). New studies, however, suggest that it is a Lion mound (S. Goolaerts, pers. comm., May 2017). Trilobites are rare there; only a few specimens of Torleyiscutellum sp. G were recovered. Bradocryphaeus sp. $\mathrm{N}$ occurs in the Neuville Member of the Champ Broquet Formation (see 3.2.).

Loc018, Nismes, embankment on the side of a rural promenade on the eastern outskirts of the village. Here the greenish shales of the Ermitage Member, Moulin Liénaux Formation, crop out. Trilobite specimens are abundant and include Bradocryphaeus maillieuxi (Richter \& Richter, 1926), Bradocryphaeus vanherlei van Viersen \& Bignon, 2011 (= type locality and horizon), Heliopyge helios (Richter \& Richter, 1926) and Cyphaspis sp. D of van Viersen \& Prescher (2007). This locality was already described by van Viersen \& Bignon (2011). It lies on the edge of "les Abannets", a small nature reserve which is the type locality of $B$. maillieuxi and $H$. helios. Most of the type material of these species is kept by the IRSNB along with numerous additional specimens for comparison.

Loc037, Boussu-en-Fagne, "ancienne carrière du Cimetière". This abandoned quarry was described by Coen-Aubert (1992). The top of the Lion Member of the Grands Breux Formation which is exposed there is highly fossiliferous, both in numbers and diversity (Vanherle, 2012, 2013). Two trilobite species, Cyphaspis koimeterionensis sp. nov. and Torleyiscutellum protrusifrons (van Viersen \& Prescher, 2011) (= type locality and horizon), co-occur here with the brachiopods "Hypothyridina" gr. cuboides (Sowerby, 1840), Parallelepipedorhynchus trapezoides Sartenaer, 2006 and Flabellulirostrum sp. (determinations by WV). The association of these brachiopods is characteristic of coeval sections along the southern border of the Dinant Synclinorium and in the Philippeville Anticlinorium.

Loc043, Frasnes, "ancienne carrière du Lion". Disused quarry in which the shales and limestones of the Grand Breux Formation as well as a Lion type mound are exposed. Trilobites include Bradocryphaeus neptuni neptuni (Bieumont Member = type locality and horizon), Torleyiscutellum sp. X (Lion Member), and Bradocryphaeus cf. laomedeia sp. nov. (Boussu-en-Fagne Member).

Loc051, Frasnes, "carrière de l'Arche". Old quarry known for its Arche bioherm in the Moulin Liénaux Formation. 
Torleyiscutellum decipulum (van Viersen \& Prescher, 2011) (= type locality and horizon) is the only trilobite known to occur here.

Loc087, Hotton, outcrop of the Bieumont Member of the Grands Breux Formation on the southern outskirts of town. This site was temporarily available during the construction of a house. Two trilobite species were found by P. Taghon and donated for study; these are assigned here to Bradocryphaeus neptuni hottonensis ssp. nov. and Bradocryphaeus laomedeia sp. nov.

Loc088, Marloie, outcrop in the Ermitage Member of the Moulin Liénaux Formation just north of town. This site was temporarily available during the construction of a building. Trilobites were collected by P. Taghon and assigned herein to Bradocryphaeus mosanus (Richter \& Richter, 1926).

Loc089, Neuville, "ancienne carrière de Beauchâteau". This is an abandoned quarry which is well known for its "marbre rouge" mined from the Petit-Mont Member of the Champ Broquet Formation (Boulvain \& Coen-Aubert, 1992). Trilobites (mostly Maillieux collection but including a specimen collected ex situ by S. Goolaerts): Torleyiscutellum sp. A.

Loc090, Ny, former railway Melreux-Manhay. Described by Asselberghs (1914) and revisited by Coen \& Coen-Aubert (1971). The site is a small outcrop just south of Ny ("section 5" of Asselberghs, 1914). A single Torleyiscutellum sp. H pygidium was recovered by WV from an ex situ, light grey limestone block along with atrypid and gypidulid brachiopods. The origin of the trilobite specimen is either the Fromelennes Formation (uppermost Givetian) or the basal part of the Nismes Formation (lowermost Frasnian).

Loc120, Hotton, outcrop in the Ermitage Member of the Moulin Liénaux Formation on the southwestern outskirts of town. This site was temporarily available during the construction of a building. Trilobite specimens belonging to two species were collected by B. Magrean and donated for study; these are assigned here to Bradocryphaeus echinatus sp. nov. and Magreanops renateae gen. \& sp. nov.

\subsection{Old localities}

Specimens in the old Maillieux collections housed by the IRSNB were examined in addition to the newly collected material. Names and one to four-digit numbers correspond to places indicated on Maillieux's field maps which are kept by the IRSNB.

Loc092. "Surice 7301" locality, just north of Surice. Lion Member of the Grands Breux Formation. Trilobites: Torleyiscutellum sp. E.

Loc093. "Han-sur-Lesse 6220" locality, just ENE of Eprave. Lion Member of the Grands Breux Formation. Trilobites: Torleyiscutellum sp. I.

Loc094. "Spy 30" locality, just northeast of Golzinne. Bovesse Formation. Trilobites: Magreanops monachus gen. \& sp. nov.

Loc095. "Olloy 8715" locality, "3ième terniat" (see Maillieux, 1913), southeast of Mariembourg. Petit-Mont Member of the Champ Broquet Formation. Trilobites: Pterocoryphe platymarginata $\mathrm{sp}$. nov.

Loc096. "Fleurus 1" locality, just north of Ligny. Bovesse Formation. Trilobites: Heliopyge cf. helios.

Loc121. "Senzeilles 7119" locality, just north of Samart. Lower (biostromal) part of the Philippeville Formation. Trilobites: Torleyiscutellum sp. C.

Loc122.Vodecée, "Carrière des Croisettes", abandoned quarry at $1100 \mathrm{~m}$ southwest of Vodecée. Petit-Mont Member of the Champ Broquet Formation. Trilobites: Torleyiscutellum sp. D.

Loc123. Emines, disused quarry just northwest of Emines. Bovesse Formation. Asselberghs (1912) described the macrofauna of the Emines locality based on material in the "le major Henne collection" which, according to him, is housed by the Katholieke Universiteit Leuven. Asselberghs illustrated trilobite specimens that he assigned to Bronteus flabellifer (= Torleyiscutellum sp. F), Cryphaeus punctatus (in all probability, conspecific with Quadratispina excelsa sp. nov.) and Dechenella verticalis (pygidia of what appears to be a dechenelline indeed; referred to herein as "Dechenella verticalis", pending revision, because that species is from the Middle Devonian of Germany and a very problematic concept as according to Richter, 1912). Unfortunately, the Henne collection could not be traced in the university at the time of this study (R. Speijer, pers. comm., April 2017). Numerous cephala and pygidia of Quadratispina excelsa sp. nov. that come from this same locality were discovered in the Maillieux collections at the IRSNB

Loc124. "Olloy 7" locality, "1ère tranchée du chemin de fer Est", southeast of Mariembourg; Nismes section of Helsen \& Bultynck (1992). Neuville Member of the Champ Broquet Formation. Trilobites: Bradocryphaeus neptuni ssp. A.

Loc125. "Beaumont 6303" locality, quarry just ESE of Solre St. Géry, no longer accessible at present. Lower part of Philippeville Formation. Trilobites: Torleyiscutellum sp. B.

Loc126. "Sautour 6147" locality, "le Rondtienne", near Sautour. Petit-Mont Member of the Champ Broquet Formation (see, e.g. Mottequin, 2005). Trilobites: Cyphaspis sp. F.

\section{Development of the Eifelian to Frasnian trilobite fauna of Belgium}

\subsection{Middle Devonian}

During the Devonian Belgium was located on the passive southern margin of Laurussia. Lower Devonian sequences are characterised here by transgressive siliciclastic sediments, the deposition of which was controlled by substantial detritic influx from the northern lying Brabant Massif. A mixed siliciclasticcarbonate ramp settled at around the Lower-Middle Devonian transition and lasted almost throughout the Eifelian. The Jemelle Formation is the main lithostratigraphic unit on the southern to

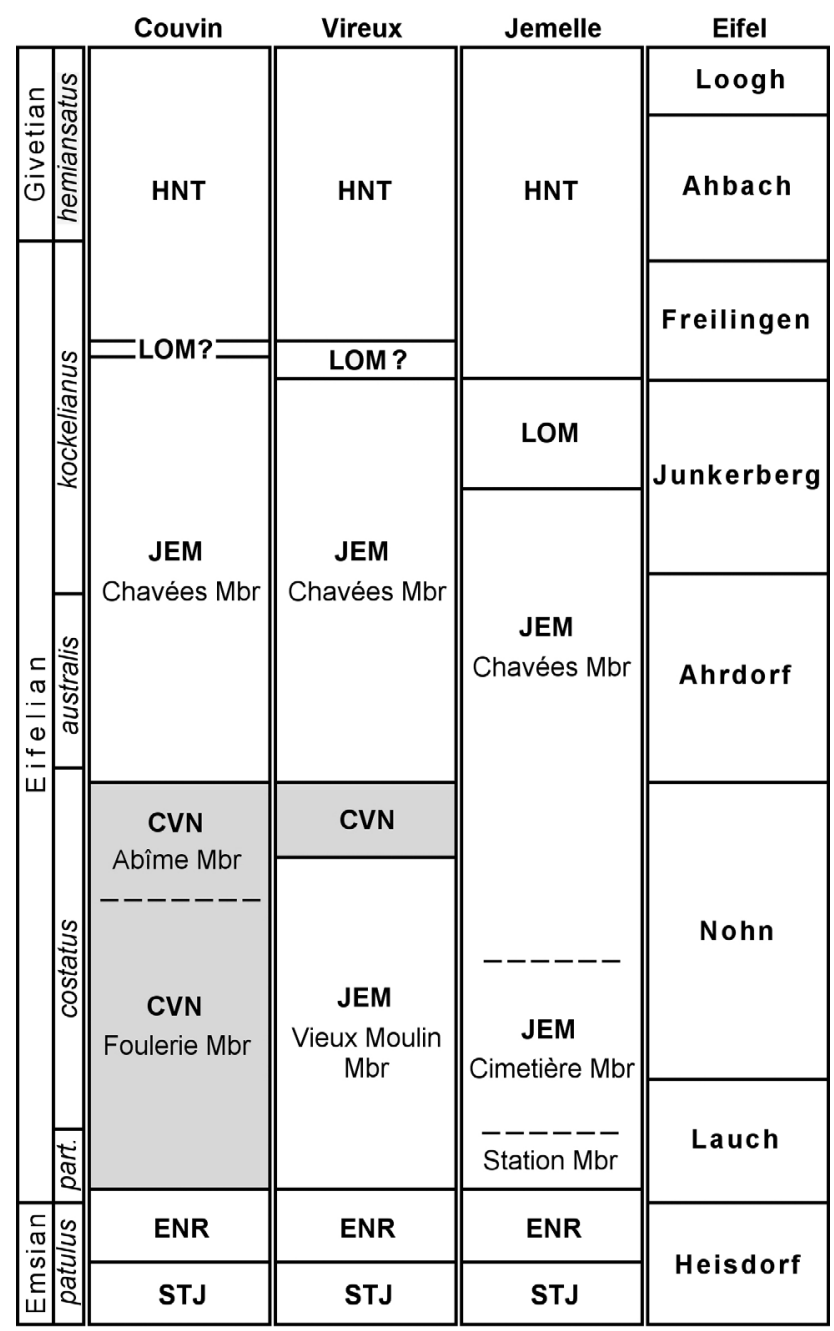

Figure 2. Schematic representation of standard latest Emsian to earliest Givetian lithostratigraphic units on the southern border of the Dinant Synclinorium (Belgium) and the Eifel (Germany). Abbreviations: Hanonet (HNT), Lomme (LOM), Jemelle (JEM), Couvin (CVN; biostrome, in grey), Eau Noire (ENR) and Saint-Joseph (STJ) formations (adopted from van Viersen et al., 2017, with changes). 
southeastern flanks of the Dinant Synclinorium (Fig. 2). It is comprised of early Eifelian siltstones and shales with a biostrome at its base (Couvin Formation) to late Eifelian shales with calcareous nodules. Trilobite diversity peaked during the middle Eifelian (australis Conodont Zone) with a conservative count of 27 genera in the Proetidae (including Tropidocoryphidae), Acastidae, Lichidae, Odontopleuridae, Scutelluidae, Harpetidae, Phacopidae and Aulacopleuridae (Fig. 3).

The highly diverse trilobite fauna from the middle part of the Jemelle Formation, inclusive of Astycoryphe, Tropidocoryphe, Cornuproetus, Austerops, Loreleiops, Diademaproetus, Ceratarges, Scabriscutellum, Thysanopeltella, Phaetonellus, Kettneraspis and Koneprusia, was drastically reduced in the upper part of this formation (van Viersen, 2015). In the adjacent German Eifel, a very similar rich "Rhenish" trilobite fauna with "Hercynian" aspect is known from the Ahrdorf Formation (australis Conodont Zone). A comparatively poorly diversified, proetid-dominated biota was recorded from the upper part of the Jemelle formation, west of Couvin by van Viersen et al. (2012), who correlated this interval and its trilobites, in part, with the Junkerberg Formation (lower kockelianus Conodont Zone) which overlies the Ahrdorf Formation in the Eifel (Fig. 2). Small bioherms high in the Jemelle Formation in the Couvin area have only yielded rare Quadratoproetus (van Viersen, 2015). The knowledge level in the Eifel is, arguably even more than in the Ardennes, defined by a sampling bias towards sections rich in trilobites or yielding specific taxa (e.g. the classic "Geeser Schichten" and "Auburg Schichten" in Kowalski, 1990).
The diachronous Hanonet Formation (uppermost Eifelian to basal Givetian) which directly overlies the Jemelle Formation where the Lomme Formation is not developed, witnessed the transformation of the Eifelian ramp into an extensive reef complex that would subsequently dominate the Givetian. Dechenella and Nyterops appear just above the base of the Hanonet Formation between Couvin and Olloy; their association with Gerastos, Goldius, Dohmiella, Cornuproetus, Astycoryphe, Radiaspis and Cyphaspis, is characteristic of the basal part of this unit. Bignon \& Crônier (2015) interpreted this latest Eifelian biota as a progressive substitution of fauna during the Kačák interval, with their late Eifelian to Givetian Dechenella association replacing the mixed association. However, as explained above and shown in the graphic chart of van Viersen (2015, p. 9, fig. 6; herein repeated as Fig. 3 and updated), the decline of the Eifelian mixed association had already started in the middle Eifelian and the most significant overhaul seems to have taken place at around the transition between the australis and kockelianus Conodont zones. These changes predate the putative positioning of the Lower Kačák Event. In fact, no evidence of this event has been found in the Ardennes (Bultynck \& Hollevoet, 1999; Gouwy \& Bultynck, 2003). Instead, a shallowing episode was recorded here at this time (e.g. the Lomme Formation) which is likely related to Struve's "Great Gap", described as a series of sedimentary gaps from Middle Devonian neritic shelf environments (Struve, 1982; Walliser et al., 1995). Except for Nyterops which is the only innovation, all trilobite genera from the basal Hanonet Formation including Dechenella (van Viersen, 2007) are components of

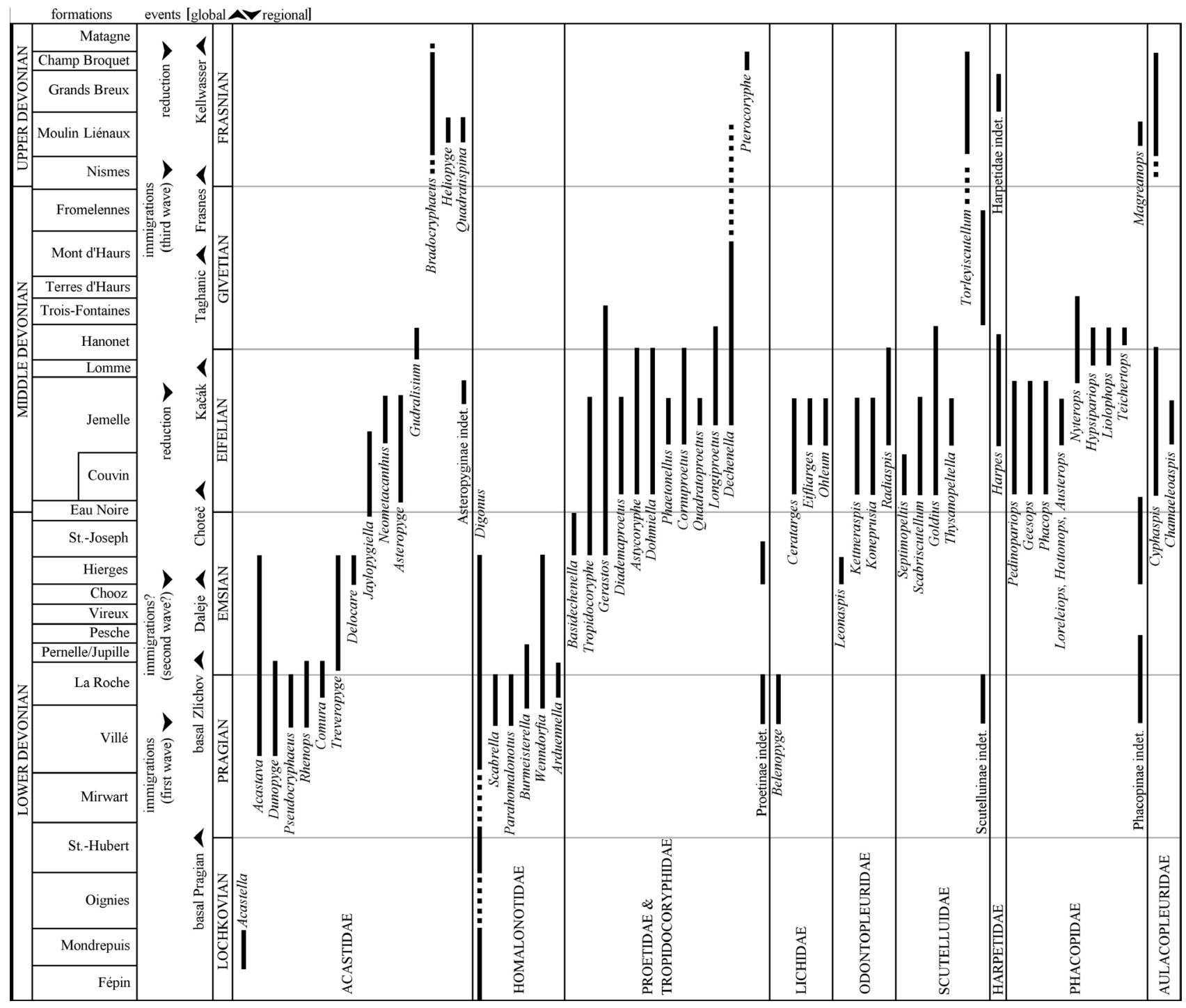

Figure 3. Stratigraphic ranges of trilobite genera in the Devonian of the Ardennes; figure adopted from van Viersen (2015, fig. 6), and updated with the weakly sculptured phacopines Austerops, Hottonops and Loreleiops recognised by van Viersen et al. (2017) and Frasnian taxa reported herein. Formations named are standard lithostratigraphic units on the southern border of the Dinant Synclinorium; their thickness and age may vary laterally and chronostratigraphic boundaries are approximate. 
the middle Eifelian associations of the Jemelle Formation (van Viersen, 2015). Thus, the basal part of the Hanonet Formation records a marked recovery (reinstallation) of the mixed association rather than a gradual transition to the Dechenella association.

The latest Eifelian upsurge of the mixed association would be short-lasted, however. By the earliest Givetian, the richly diversified trilobite faunas of the Eifelian mixed ramp environments in Belgium were decimated: the largest group, the proetids, had lost most of its diversity (van Viersen \& Prescher, 2010); odontopleurids and aulacopleurids are not known from above the Givetian boundary (van Viersen, 2015). The last occurrences of Cornuproetus, Dohmiella, Astycoryphe, Cyphaspis and Radiaspis can be observed close to the EifelianGivetian boundary in the abandoned Resteigne quarry. Except for Cyphaspis and Radiaspis which continued elsewhere, these genera went globally extinct at around this time or shortly after. Trilobite diversity drops are witnessed in latest Eifelian to early Givetian sections worldwide and have been attributed to the Lower Kačák Event (Chlupáč, 1994) although at times perhaps somewhat arbitrarily. Further investigations will be required in order to come to a better understanding of trilobites in relation to the changing palaeoenvironment during the Eifelian-Givetian transition in Belgium.

The "main" Givetian macrofauna of Belgium was chiefly comprised of corals, stromatoporoids and brachiopods. Trilobites were poorly diversified, encompassing proetids, scutelluids and phacopids. These were mostly restricted to back-reef environments (Bignon \& Crônier, 2015).

\subsection{Frasnian}

Gouwy \& Bultynck (2000) recognised four T-R cycles in the Belgian Frasnian (Fig. 4) as opposed to three in the global T-R chart of Johnson et al. (1985). The first cycle corresponds to a general increase in faunal diversification at the end of the Givetian. It signified the opening of the Givetian carbonate platform which was subsequently "drowned" in the basal Frasnian (Nismes Formation). No trilobite occurrence in the Nismes Formation could be corroborated during our study. However, the transgressive character of this unit and its shaly facies similar to the trilobite-bearing middle Frasnian strata of Belgium, were particularly suitable for acastids that radiated palaeogeographically during this interval. Maillieux (1940) provided lists of macrofaunal elements from units "F2a, zone à Spirifer orbelianus" and "F2b, zone à Spirifer bisinus" which correspond to the Nismes Formation (Fig. 4). He only reported trilobites in "F2b" which he identified as Asteropyge (Asteropyge) supradevonica (the type species of Bradocryphaeus) and Otarion cf. ibergia (in all probability congeneric with species assigned to Cyphaspis below). We were unable to trace this material. However, in view of the circumstantial evidence it is conservative to assume the presence of Bradocryphaeus and Cyphaspis, or morphologically similar genera, in the Nismes Formation.

Second T-R cycle: Starting with the development of the Arche mounds in the Moulin Liénaux Formation near the base of the punctata Conodont Zone. Trilobites are found associated with both the mounds and lateral facies although diversity is much higher in the latter. In the northern belt a more or less coeval, fairly diverse trilobite association including proetids (Dechenellinae) and acastids (Quadratispina) not found elsewhere in Belgium, has long been known from the dark limestones of the Bovesse Formation (Asselberghs, 1912). Acastids (Bradocryphaeus, Heliopyge, Quadratispina) are the dominant trilobites in the shales and limestones of the southern and northern belts (heretofore undiscovered in the intermediate belt) although it must be emphasised that their diversity is almost entirely covered by Bradocryphaeus. Heliopyge has long been known exclusively from the southern border of the Dinant Synclinorium (Nismes); a second occurrence in the Namur Basin (Ligny) can now be added. Scutelluids (Torleyiscutellum) are the only trilobites found associated with the reef environments but they might not be confined to these: an undescribed species occurs in the proximal facies of the Bovesse Formation (Asselberghs, 1912, p. 38, pl. 6, fig. 12a, b). However, because the original material was unavailable its sedimentology could not be assessed. In this context it is noteworthy that Dormal (1888) reported what he interpreted as small mounds, enclosed within the shales of the Bovesse Formation. Thus, the occurrence of Torleyiscutellum in the Bovesse Formation must be validated. There are also exceptional cases of scutelluids from lateral facies on the southern border of the Dinant Synclinorium but those specimens are very fragmentary and have only been found in the vicinity of the mounds. Such occurrences likely represent mechanically reworked sclerites originating from the nearby reefs (van Viersen, 2015). Phacopids (Magreanops) are rare and only known from the lateral facies in the northern and southern belts. Aulacopleurids (Cyphaspis) are restricted to the upper part of the Ermitage Member of the Moulin Liénaux Formation (southern belt).

Third T-R cycle: Starting just above the base of the hassi Conodont Zone with the diachronous Bieumont Member and the development of the Lion mounds in the Dinant Synclinorium. Trilobite diversity in the Grands Breux Formation is different from the underlying Moulin Liénaux Formation in that an increase at the genus level is observed in the reefal environments but at the cost of the lateral facies. Limestones and shales have chiefly yielded acastids although the diversity of the family is clearly reduced with Bradocryphaeus as the sole genus. Bradocryphaeus neptuni is widespread, occurring in the Bieumont Member and lower half of the Boussu-en-Fagne Member at the Lompret, Frasnes and Hotton sections, while demonstrating a mild preference for limestones. Bradocryphaeus laomedeia, however, while co-occurring with $B$. neptuni in the basal limestones of the Bieumont Member at the Hotton section, is known in the Boussuen-Fagne Member exclusively from shales. Dormal (1888) listed "Cryphaeus arachnö̈deus" (sic) and Phacops sp. for the Rhines Formation: the former is an acastid, presumably belonging to Bradocryphaeus or Quadratispina; the latter might be a phacopid (Dormal's original material could not be traced and he did not provide illustrations). Aulacopleurids (Cyphaspis) remain poorly diversified although by now they have invaded reef environments in the southern belt. Fairly numerous specimens of Cyphaspis koimeterionensis have been recovered from the upper part of the Lion mound exposed at the Boussu-en-Fagne section. Scutelluids (Torleyiscutellum), while still showing no major innovations, are more diversified with several (at least two) species identified in Lion type mounds. Torleyiscutellum furthermore occurs in the biostromal lower part of the Philippeville Formation in the Philippeville Anticlinorium. Harpetids (see van Viersen \& Bignon, 2011) are only known from shales near Frasnes.

Fourth T-R cycle: The semichatovae transgression represents a brief global eustatic deepening in the early upper Frasnian named after the index fossil Palmatolepis semichatovae (Sandberg et al., 2002). This event was identified by Gouwy \& Bultynck (2000) in the lower part of the Champ Broquet Formation. The latter unit was defined by Coen Aubert (2015) to encompass the former Neuville Formation and Petit-Mont type mounds on the southern border of the Dinant Synclinorium and is furthermore inclusive of the Les Valisettes Member in the Philippeville Anticlinorium (Fig. 4). The Petit-Mont mounds are traditionally known for their hematitic limestones (informally called "marbres rouges") such as those exposed in the disused Beauchâteau quarry. The origin of the red pigmentation has long remained a matter of debate but recent studies point to iron bacteria as being a likely source (Boulvain et al., 2001). The trilobites of the Champ Broquet Formation are historically associated with these mound levels. Scutelluids (Torleyiscutellum) are dominant and specimens can be fairly common locally whereas Cyphaspis is very rare. The unique discovery of a pygidium of the pteropariine Pterocoryphe is of great palaeobiogeographic importance (see 5.4.). The lateral facies of the Champ Broquet Formation have yielded the last confirmed Bradocryphaeus specimens from Belgium which occur high in the Neuville Member at the Lompret section (designated Bradocryphaeus sp. N in Fig. 4); these will be described elsewhere (S. Goolaerts \& AV, work in progress).

\subsection{Frasnian extinction patterns}

The Frasnian-Famennian extinction was named the "Kellwasser Event" by House (1985) in reference to the widely distributed, blackish Lower and Upper Kellwasser Limestones. More recently, the notion was developed that rather than mass depletion as the 


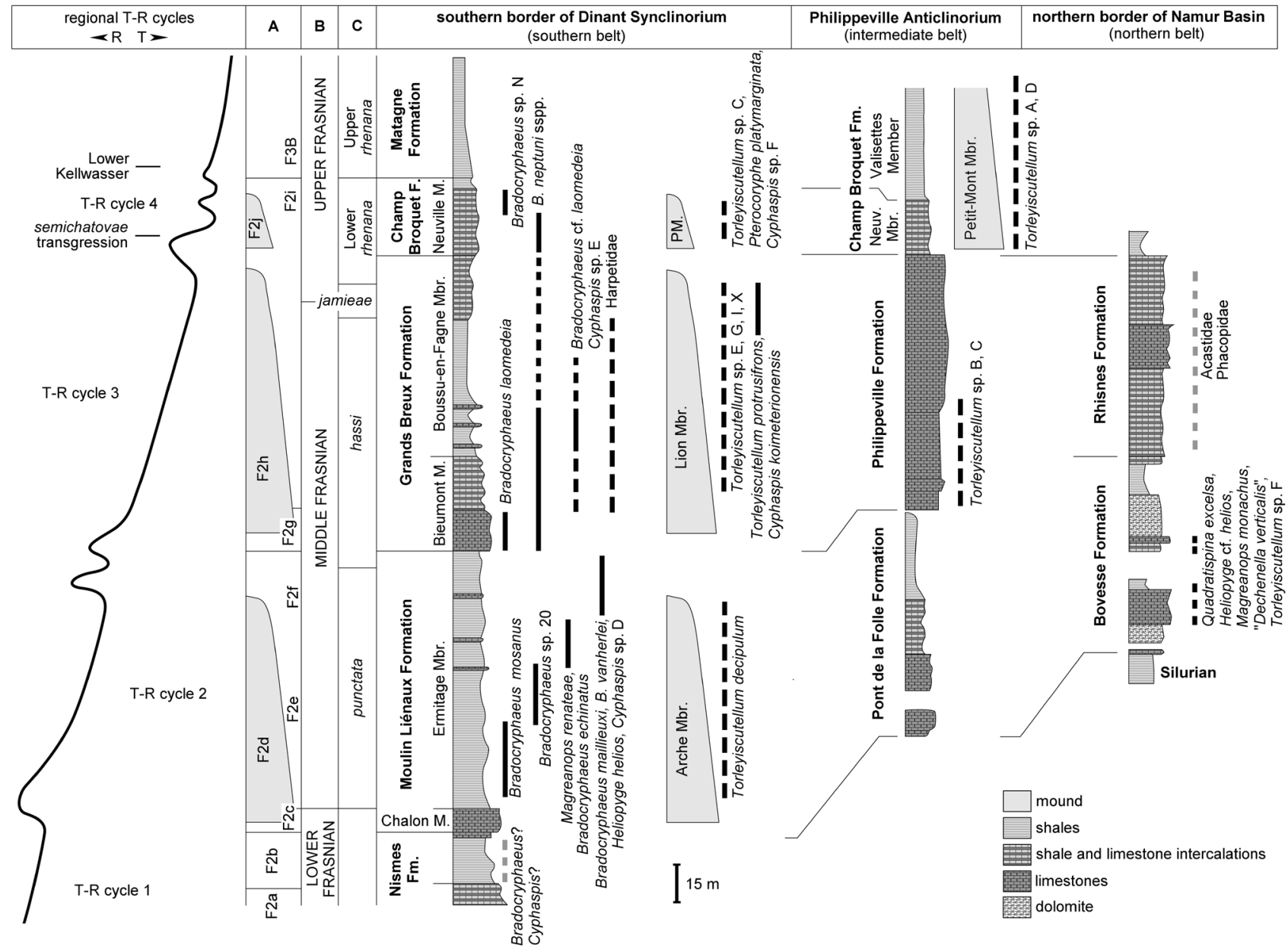

Figure 4. Selected Frasnian formations in Belgium including lithostratigraphic columns, adopted from Boulvain et al. (1999) and modified after CoenAubert (2015), including old subdivisions (A), chronostratigraphy (B), standard conodont zones (C), and maximum stratigraphic ranges of trilobite taxa in the southern, intermediate and northern belts (black dotted lines are tentative indications of occurrences; grey dotted lines are unsubstantiated records in the old literature). Regional T-R cycles adopted from Gouwy \& Bultynck (2000).

product of periodic elevated extinction, the Kellwasser Event reflects increased attrition rates linked to reduced origination (Bambach et al., 2004). Notwithstanding the unquestionably widespread ecosystem perturbations caused by the Kellwasser Event, its effects remain inadequately positioned in a broader, Late Devonian context (Racki, 2005).

Feist \& Schindler (1994) noticed that by late Frasnian times, trilobite associations encompassed only obligate bottom-level inhabitants adapted to low-light conditions. They postulated that most trilobites from the linguiformis Conodont Zone were blind, probably endobenthic forms, unable to cope with the sudden and widespread dysoxia of the Upper Kellwasser level. Indeed, drastic diversity drops at sections in Europe and North Africa occurred at the Upper Kellwasser level. The situation is somewhat different in the Canning Basin (NW Australia) where one of the best preserved Devonian reef complexes in the world is exposed. McNamara \& Feist (2016) described how trilobite diversity was exceptionally high prior to the Lower Kellwasser level with representatives of Harpetidae, Scutelluidae, Odontopleuridae, Phacopidae, Aulacopleuridae and Proetidae (including Tropidocoryphidae). In the two regional conodont zones preceding the Lower Kellwasser level origination rates were equal to extinction rates but none of the 23 species in both zones survived the Lower Kellwasser level. The same applies to the interval between the two Kellwasser levels, until all 40 species described from the Frasnian in the Canning Basin went extinct at the Upper Kellwasser level. Here there is no evidence of dysoxia; instead, both levels are correlated with the onsets of major regressions. Such examples demonstrate the destructive effects of the Kellwasser Event on trilobite associations which is, with right, considered an extinction.

In Belgium the intensity of the Kellwasser Event and its effects on benthic biotas depended on their position along the ramp (Mottequin, 2008a). The Lower Kellwasser level is marked by the deposition of dark shales (Matagne Formation) on the southern border of the Dinant Synclinorium (Gouwy \& Bultynck, 2000). The sudden but diachronous, widespread darkening of the sediments is considered to evidence the onset of hypoxic or anoxic conditions. In the Philippeville Anticlinorium, the base of the Matagne Formation corresponds to the Upper Kellwasser level whereas the Lower Kellwasser level is positioned in the Les Valisettes Member of the underlying Champ Broquet Formation (Bultynck et al., 1998; Gouwy \& Bultynck, 2000). The late Frasnian decline of brachiopods in shelf environments occurred in a step-wise fashion until a major crisis was recorded just below the Upper Kellwasser level (Mottequin, 2008a, b; Mottequin \& Poty, 2015). Major turnovers in the ostracod fauna close to the Kellwasser Event have been interpreted as episodic hypoxia followed by a major regression close to the Frasnian-Famennian boundary (Casier, 2017). The Lower Kellwasser level had no noticeable effect on corals as it trailed the first coral extinction which corresponds to a shift in the depositional pattern at around the middle-upper Frasnian boundary (Poty \& Chevalier, 2007).

The presently available data reveal that Frasnian trilobite diversity in Belgium was highest within the punctata Conodont Zone with 14 species (including taxa in open nomenclature) in 7 genera (Fig. 4). The shales with few limestone intercalations of the Ermitage Member were particularly suitable for members of Bradocryphaeus which are locally truly abundant. The first significant diversity cut happened in conjunction with the termination of the Arche mounds. For Torleyiscutellum this is particularly obvious because its occurrence was restricted to reefal environments. Only Bradocryphaeus lineages continued without noticeable interruption into the hassi Conodont Zone as members of the genus quickly established widespread foothold in the mud- and limestones of the Bieumont Member. Trilobites 
from the hassi and jamieae Conodont zones include a larger amount of taxa in open nomenclature: up to 13 distinct species in 4 genera potentially occur here (Harpetidae included; Acastidae and Phacopidae from the Namur Basin excluded) although the number of 6 Torleyiscutellum species described in open nomenclature is likely to be much reduced as better preserved material becomes available (see below). None of these species made it until the Lower rhenana Conodont Zone except for $B$. neptuni. A final, brief diversity upsurge occurs in this last zone with at least 5 species in 4 genera, none of which persisted into the Upper rhenana Conodont Zone.

Based on these figures a general reduction of trilobite diversity during the middle to late Frasnian in Belgium might be advocated. This is certainly true for the associations of the lateral facies which lost most of their diversity after the collapse of the Arche mounds and remained at a decline. The associations of the reefal environments on the other hand, although fully removed along with the termination of each mound level, repeatedly convalesced rather well subsequent to the reinstatements of their habitats. In fact, a modest diversity increase is observed in the mound levels throughout the Frasnian. It is striking that except for members of the highly successful and stratigraphically longranging Cyphaspis (see below), no trilobite appears to have been able to switch between the reefal and lateral environments. Thus, a distinction must be made between trilobite extinction patterns in the reefal and lateral facies of the Belgian Frasnian for they are principally different.

The role of the Kellwasser Event in the demise of the trilobite fauna remains inconclusive. No stratigraphically controlled data from around the Kellwasser levels were available during our study. Consequently, we can only possibly speculate on their impact by assessing the quality of the habitats of the trilobites. The termination of the last (Petit-Mont) mound level happened prior to the Lower Kellwasser level in the southern Dinant Synclinorium and in between both Kellwasser levels in the Philippeville Anticlinorium. Thus, if the reefal trilobite associations did in fact cease to exist with the final removal of their habitats then they could well have been present above the Lower Kellwasser level in the latter depositional area. The trilobites of the lateral facies appear to exhibit a more step-wise decline. It stands, however, that not a single trilobite is known with certainty from levels above the first darkening of the sediments. Maillieux (1936) mentioned the occurrence of Bradocryphaeus supradevonicus basally in the Matagne Formation but we have not been able to trace this material. Notwithstanding the devastating potential of the Kellwasser levels on trilobites as showcased in other countries, the currently available data suggest that the Belgian Frasnian trilobite fauna was already at a decline prior to this event, as a consequence of the deteriorations or losses of shallowwater habitats attested to by some other fossil groups.

\section{Systematic palaeontology}

All the figured specimens were whitened with ammonium chloride prior to photography. The type material is housed by the Institut royal des Sciences naturelles de Belgique (IRSNB). Occurrences provided for each of the genera below encompass exclusively records from Belgium.

Our study was based both on our contemporary fieldwork in cooperation with private collectors and examinations of old museum collections. Although research has been exhaustive it must be considered that 1) the number of latest Frasnian outcrops that are open and suitable to collectors is limited; 2) it can be assumed, a priori, that there is a sampling bias towards sections that yield a richer macrofauna; 3 ) trilobites were often collected under limited stratigraphic control (this is particularly the case for old museum collections which make up a major part of the data).

Family Aulacopleuridae Angelin, 1854

Subfamily Otarioninae Richter \& Richter, 1926

Tribe Otarionini Richter \& Richter, 1926

\section{Genus Cyphaspis Burmeister, 1843}

Type species. Phacops ceratophthalmus Goldfuss, 1843.
Species assigned. This genus is in need of revision. Van Viersen \& Holland (2016) have outlined the basic problems and grouped species based on major morphological trends. However, they emphasised that none of their groups are demonstrably monophyletic, nor does their collection account for the total generic diversity.

Discussion. According to its present definition Cyphaspis ranges from the Silurian to Late Devonian. Most stratigraphically older species exhibit a strongly vaulted glabella with distinct anterior overhang. This has been considered an important distinguishing feature from its sister taxon, Otarion Zenker, 1833 (Adrain \& Chatterton, 1994). The Emsian to Frasnian, however, gave rise to many convergences, i.e., putative Cyphaspis species with a weakly inflated, Otarion-like glabella (compare, e.g. the hamidi group of van Viersen \& Holland, 2016). Most of the Frasnian forms (e.g. Richter \& Richter, 1926; McNamara \& Feist, 2016) have been assigned to Otarion based on their weakly vaulted median glabellar lobe. The importance of the glabellar morphology to the generic assignments of derived species is open to debate (e.g. Basse, 2002; van Viersen \& Prescher, 2007). We attribute the Frasnian otarionines described in this study to Cyphaspis based on the presence of inflated genal trunks. According to Adrain \& Chatterton (1994) this feature is developed in Cyphaspis and several other genera but never in Otarion.

Occurrence. Members of Cyphaspis are widespread in Eifelian strata, occurring in the Jemelle, Couvin and Hanonet formations. They are not known from the Givetian but reappear in Frasnian strata where they are rare and mostly restricted to Lion type mounds. Few specimens are known from lateral shales: substantiated records come from the Ermitage (Cyphaspis sp. D of van Viersen \& Prescher, 2007, pl. 2, fig. 8) and Boussu-en-Fagne members of the Moulin Liénaux and Grands Breux formations, respectively. Additionally, a single specimen is recorded from a Petit-Mont type mound.

\section{Cyphaspis koimeterionensis sp. nov.}

(Figs 5A-D, F-H)

v 1926 Cyphaspis ibergia Richter \& Richter, pl. 7, fig. 10.

e.p. 1927 Otarion ibergia R. et E. Richter, 1926; Maillieux, p. 78 [only material from "carrière du Cimetière"].

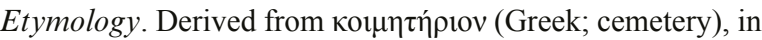
reference to the type locality "carrière du Cimetière".

Holotype. IRSNB a13165, cephalon (Figs 5F-H).

Paratypes. IRSNB a7781, a13183 (Figs 5A-D), a13218, three cephala, from type locality and horizon.

Type locality and horizon. Loc037, Boussu-en-Fagne; Lion Member of the Grands Breux Formation.

Diagnosis. Widely rounded cephalon with anteriorly slightly anteriorly protruding outline. Preocular suture running straight in anterior view; in dorsal view $\gamma$ and $\beta$ are on the same exsagittal line, with $\alpha$ located just adaxial to this line. Length of L1 (exsag.) relative to length of glabella anterior to $\mathrm{S} 0 \approx 0.45$.

Description. Occipital ring as high as central part of median glabellar lobe; slightly shorter (exsag.) abaxially than centrally. Teardrop-shaped L1 reaching anteriorly at least until lateral to facial suture point $\varepsilon$; well demarcated by deep furrows. Median glabellar lobe elongated bulb-shaped with straightened (exsag.) flanks; slightly longer than high and with minor anterior overhang. Preglabellar field short (sag., exsag.); slightly anteriorly dorsally protruding medially, where a large depression is developed in the adjacent part of the preglabellar furrow (see below). Fixigena lateral to eye as wide as L1 (tr.); highest point is much lower than occipital ring. Postocular suture running straight proximally, making a gentle curve anteriorly towards $\varepsilon$. Eyes not preserved; their bases are ellipsoidal (exsag.). Librigenal field longer (exsag.) than wide (tr.) in lateral view; steep (tr.); with 

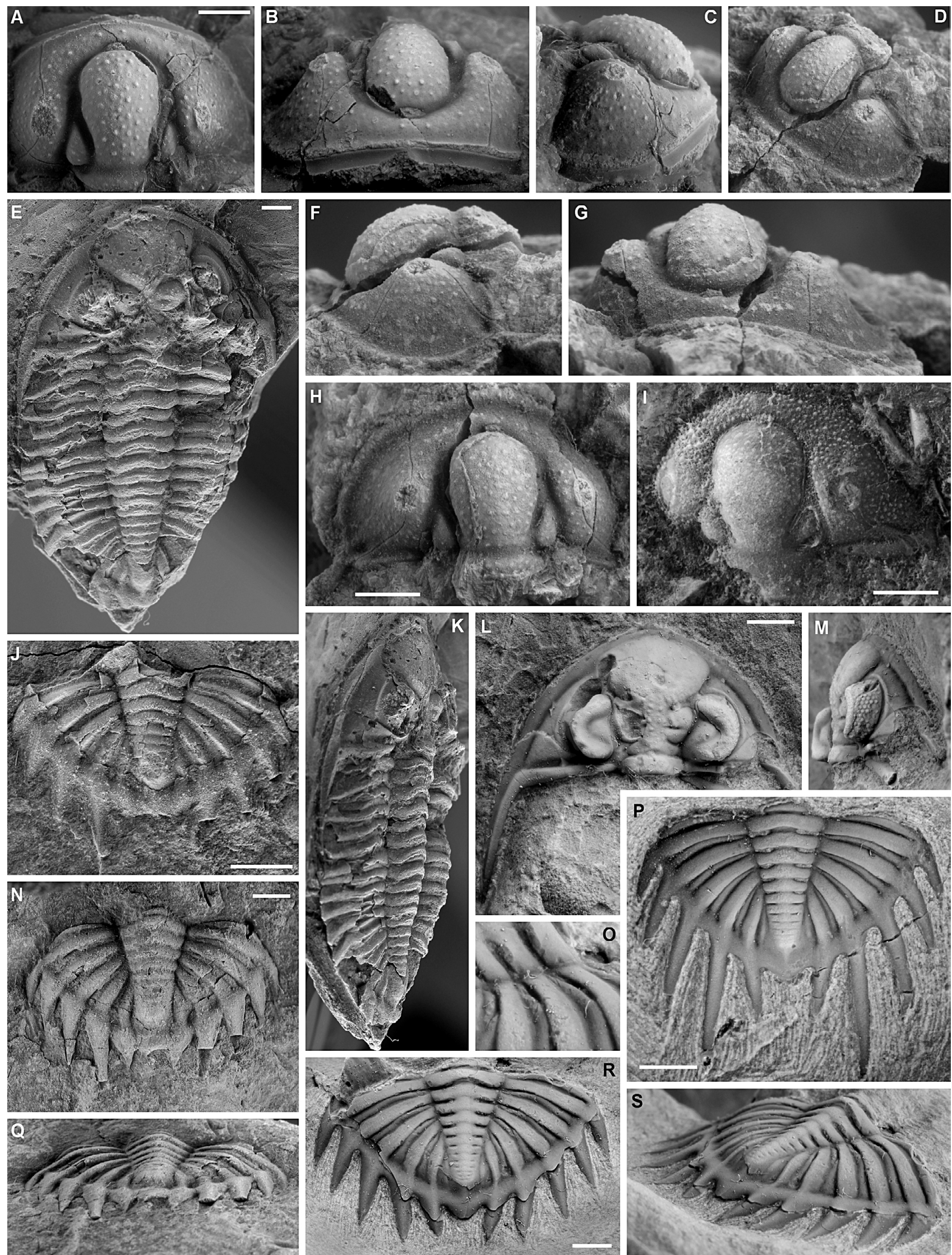

Figure 5. A-D, F-H. Cyphaspis koimeterionensis sp. nov. from the Lion Member of the Grands Breux Formation at Loc037, Boussu-en-Fagne. Paratype cephalon with exfoliated anterior border, IRSNB a13183, in dorsal (A), anterior (B), lateral (C) and oblique anterior (D) views. Holotype cephalon, IRSNB a13165, in lateral $(\mathrm{F})$, anterior $(\mathrm{G})$ and dorsal $(\mathrm{H})$ views.

E, J, K, N, Q. Bradocryphaeus neptuni ssp. A from the Neuville Member of the Champ Broquet Formation at Loc124, Mariembourg. Complete specimen, IRSNB a13187, in dorsal (E) and oblique lateral (K) views. Pygidium, IRSNB a13185, in dorsal view (J). Pygidium, IRSNB a13186, in dorsal $(\mathrm{N})$ and posterior $(\mathrm{Q})$ views.

L, M, O, R, S. Bradocryphaeus neptuni hottonensis ssp. nov. from the Bieumont Member of the Grands Breux Formation at Loc087, Hotton. Paratype cephalon, IRSNB a13205, in dorsal (L) and lateral (M) views. Holotype pygidium, IRSNB a13206, in close-up of right anterior three pleurae (O), dorsal (R) and oblique posterior (S) views.

P. Bradocryphaeus laomedeia sp. nov. from the Bieumont Member of the Grands Breux Formation at Loc087, Hotton. Holotype pygidium, IRSNB a13207, in dorsal view.

All scale bars represent $2 \mathrm{~mm}$. 
fairly well-developed genal trunk. Genal spines are short (if not broken off); their oblique bases are directed more posteriorly than laterally. Shallow, broad cephalic border furrow. Weakly inflated anterior to lateral cephalic borders; slightly flattened lateral of the eye. Entire cephalon covered with moderately closely spaced tubercles. Preglabellar field bears three pairs of slightly enlarged tubercles.

Discussion. The new species is similar to Cyphaspis ibergia from the Iberger Kalk (Frasnian) of Germany. The latter is discriminated by its narrower (tr.) cephalic outline, narrower glabella, smaller L1, eyes positioned far posteriorly relative to glabella, and long genal spines. While describing $C$. ibergia Richter \& Richter (1926, pl. 7, fig. 10) included an incompletely prepared cephalon from Boussu-en-Fagne in their type series (IRSNB a7781, examined by us and selected herein as paratype of $C$. koimeterionensis sp. nov.) and provided a drawing. This drawing, however, is misleading in that it depicts a seemingly complete cephalon in lateral view with only an exfoliated cephalic border. Possibly, this drawing was enhanced using some of the numerous other cephala that are kept in the Maillieux collection.

Trenkner (1867) described Cyphaspis ellipsocephalus (sic) on the basis of a single glabella from "the Iberger Kalk of Winterberg", Germany. Richter \& Richter (1926) complemented the description of this species using specimens from various places, none of which is the type locality. We consider a single glabella to come short to warrant the description of a new species. The holotype cannot be adequately compared with the supplementary material of Richter \& Richter (1926) and so their putatively conspecific relationship cannot be corroborated. Since the type locality is not known exactly and no other topotype specimens have been identified we regard C. ellipsocephala as a nomen dubium.

Cyphaspis stigmatophthalmus (Richter, 1914) from the upper Frasnian in Germany (Richter \& Richter, 1926, pl. 7, figs 11-16; Feist, 1995, p. 229, fig. 11.2; Feist \& Schindler, 1994, pl. 4, figs 9, 10, 15), Montagne Noire (Feist \& Schindler, 1994, pl. 4, figs 11-14) and Morocco (Feist, 2002, fig. 3J, K) has a long (sag.) preglabellar field, very small L1, and a median tubercle. On the other hand it shares with our species the development of a median depression in the preglabellar furrow (filled with sediment in our specimens).

Maillieux (1927, p. 78) reported Otarion ibergia in "F2j, petit récif rouge" in the Cimetière Quarry. This refers to the PetitMont Member. All of the specimens in the IRSNB are from a grey limestone. These are identical to our material from the top of the Lion Member. A Petit-Mont type mound is shown on the revised geological map in the northern part of the quarry but is no longer accessible at present.

\section{Cyphaspis sp. E}

(Fig. 6R)

Material. IRSNB a13171, incomplete cranidium on a single rock slab together with Bradocryphaeus cf. laomedeia sp. nov. from Loc011, Lompret; Boussu-en-Fagne Member of the Grands Breux Formation.

Discussion. The single cranidium is indeterminable. Of note are the long (sag., exsag.) occipital ring with densely spaced pustules and what appears to be the base of a median tubercle or thorn posteriorly, the large L1, and the smooth, wide (tr.) fixigena with large base of an eye lobe and steeply inclined front.

\section{Cyphaspis sp. F}

(Fig. 5I)

Material. IRSNB a13184, external mould of a cephalon from Loc126, Sautour; Petit-Mont Member of the Champ Broquet Formation.

Discussion. This is the sole confirmed Cyphaspis specimen from a Petit-Mont mound. The specimen is not very well preserved but easily distinguished from Cyphaspis koimeterionensis by the longer (sag., exsag.) occipital ring, shallow S0, shorter L1, and longer preglabellar field. These features and the stratigraphically high occurrence of $C$. sp. F suggest a closer relationship to Cyphaspis stigmatophthalmus instead.

Family Proetidae Salter, 1864

Subfamily Pteropariinae Hupé, 1953

\section{Genus Pterocoryphe Feist, 1976}

Type species. Pterocoryphe languedociana Feist, 1976 from the Frasnian of the Montagne Noire.

Species assigned. Pterocoryphe larouquettensis Feist, 1976; Pterocoryphe progrediens Feist \& Clarkson, 1989; Pterocoryphe platymarginata sp. nov.

Occurrence. Pterocoryphe is restricted to a single species from grey limestones of the Petit-Mont Member in the vicinity of Mariembourg.

\section{Pterocoryphe platymarginata sp. nov.}

(Fig. 10C)

v 1940 Drevermannia palpebralis R. E. Richter; Maillieux, p. 32 [material from "Olloy 8715"].

v 2015 Drevermannia; van Viersen, pp. 9, 17.

Etymology. Combination of $\pi \lambda \alpha \tau v ́ \varsigma$ (Greek; flat, broad) and marginatus (Latin; bordered).

Holotype. IRSNB a13194, external mould of a pygidium (Fig. 10C).

Type locality and horizon. Loc095, Mariembourg; PetitMont Member of the Champ Broquet Formation.

Diagnosis. Pygidium with seven or eight weakly vaulted (tr.) axial rings only the anterior four of which are separated by distinct inter-ring furrows, the remaining axial rings being recognisable through the presence of median tubercles. Long, narrow pygidial axis; fourth axial ring distinctly more tapered than third. Pygidial border of equal width throughout.

Discussion. Van Viersen (2015) listed "Drevermannia" in the Frasnian of Belgium, referring to the earlier identifications of Drevermannia palpebralis by Maillieux (1940). Having examined the original material, a pygidium in the collections of the IRSNB, it has become clear that this taxon should be assigned to Pterocoryphe instead.

Pterocoryphe platymarginata is similar to Pterocoryphe larouquettensis from the middle Frasnian (middle part of hassi Conodont Zone) in the Montagne Noire. The French species is different in having a more uniformly tapering pygidial axis with deeper inter-ring furrows and larger median tubercles; the pygidial border is broadest (sag.) posteromedially and tapers anteriorly (this is nowhere the case in the Belgian species which has much narrower pleural fields as a result). Although the discovery of a cephalon of $P$. platymarginata would be timely, the described differences are sufficient for its recognition as a distinct species.

Family Acastidae Delo, 1935

Subfamily Asteropyginae Delo, 1935

\section{Genus Bradocryphaeus Haas \& Mensink, 1970}

Type species. Cryphaeus supradevonicus Frech, 1888.

Species assigned. In performing a cladistic analysis on Asteropyginae Bignon \& Crônier (2014) emended the diagnosis of Bradocryphaeus and revised the list of species assigned. Some of these species are referred herein to Quadratispina Gandl, 1972 (see below).

Discussion. There appear to be two morphological groups within Bradocryphaeus during the middle Frasnian in Belgium 

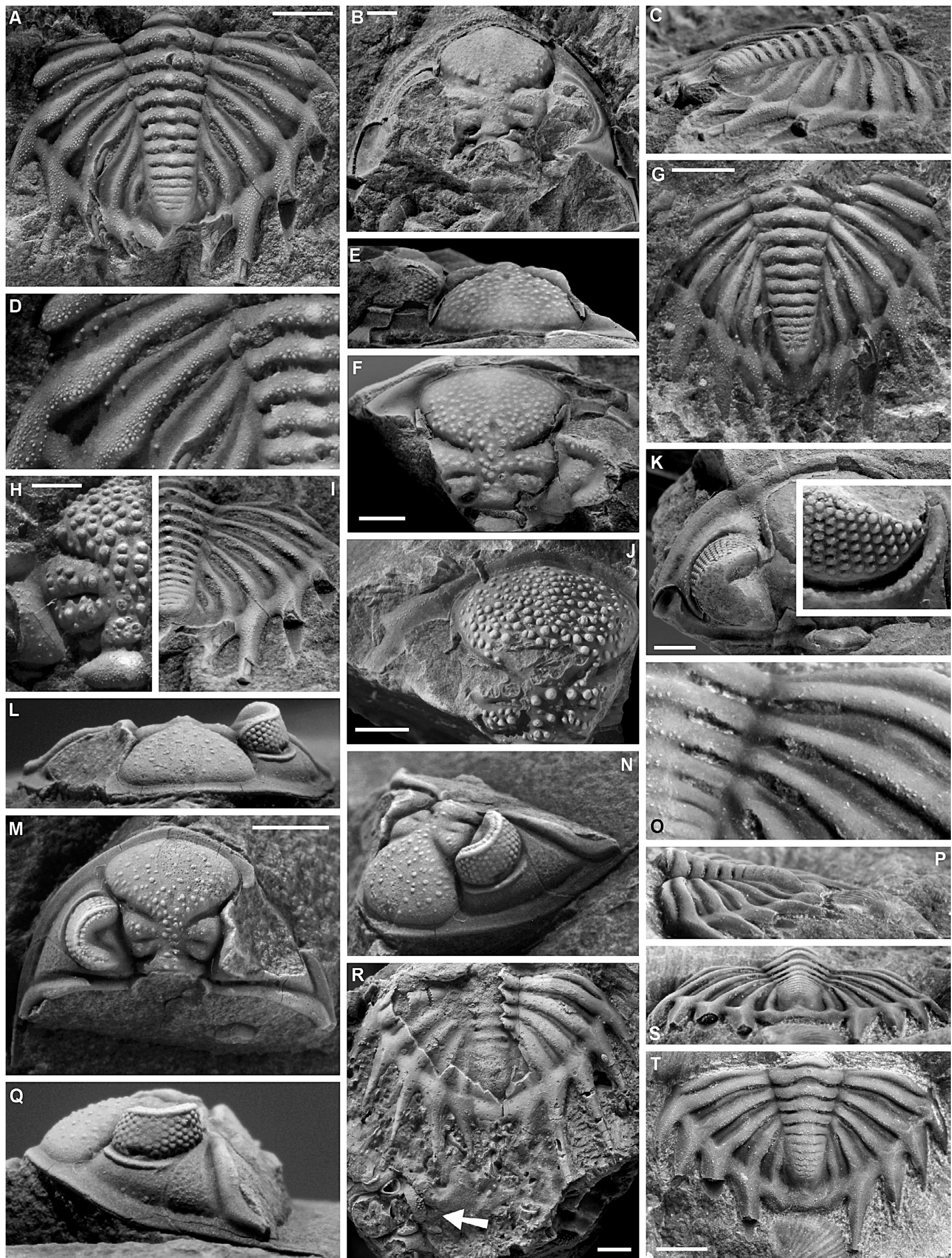

Figure 6. A-K. Quadratispina excelsa sp. nov. from the Bovesse Formation at Loc123, Emines. Holotype pygidium, IRSNB a13195, in dorsal (A), oblique lateral (C), close-up of left pleural field (D) and oblique posterior (I) views. Paratype cephalon, IRSNB a13196, in dorsal view (B). Paratype cephalon, IRSNB a13197, in anterior (E) and dorsal (F) views. Paratype pygidium, IRSNB a13200, in dorsal view (G). Fragmentary cephalon, IRSNB a13201, close-up of left part of glabella (H). Paratype incomplete cephalon, IRSNB a13198, in dorsal view (J). Paratype incomplete cephalon, IRSNB a13199, in dorsal view with inset showing left eye in lateral view (K).

L-Q, S, T. Bradocryphaeus neptuni neptuni van Viersen \& Bignon, 2011 from the Boussu-en-Fagne Member of the Grands Breux Formation at Loc011, Lompret. Cephalon, IRSNB a13169, in anterior (L), dorsal (M), oblique anterolateral (N) and lateral (Q) views. Pygidium, IRSNB a13170, in dorsal close-up of right pleural field and axis $(\mathrm{O})$, lateral $(\mathrm{P})$, posterior $(\mathrm{S})$ and dorsal $(\mathrm{T})$ views.

R. Pygidium of Bradocryphaeus cf. laomedeia sp. nov. and cranidium of Cyphaspis sp. E (arrow), IRSNB a13171, from the Boussu-en-Fagne Member of the Grands Breux Formation at Loc011, Lompret.

All scale bars represent $2 \mathrm{~mm}$ 
(Fig. 7): one is inclusive of forms with short pygidial pleural spines (fourth pair of pleural spines $\leq$ length of associated pleurae), often of rounded triangular section (tr.); the other group encompasses species with long pygidial spines (fourth pair of pleural spines is at least 1.5 times length of associated pleurae) of broadly rounded section. Members of neither group are confined to certain facies. The phylogenetic importance of both groups must be assessed in a broader investigation that is to include species from other countries. This is beyond the scope of the present paper.

Occurrence. Bradocryphaeus occurs both in the shales and limestones of the Nismes (?), Moulin Liénaux, Grands Breux and Champ Broquet formations; it has never been found associated with any of the bioherms.

\section{Bradocryphaeus mosanus (Richter \& Richter, 1926)}

(Fig. 7; Figs 8D-J, L)

v e.p. * 1926 Asteropyge (Asteropyge) mosana Richter \& Richter, pp. 218, 219, pl. 12, fig. 32 [non pl. 12, fig. $33=B$. cf. mosanus].

e.p. 1927 Asteropyge (Asteropyge) mosana; Maillieux, pp. 82,83 [only Givet].

2011 Bradocryphaeus mosanus; van Viersen \& Bignon, p. 115. 2014 B. mosana (sic); Bignon \& Crônier, p. 662.

2014 B. mosanus; Bignon \& Crônier, p. 663.

Material. IRSNB a7789, holotype partially exfoliated pygidium, the associated negative imprint of which is refigured (digitally inverted) in Fig. 7 as "B. mosanus, Givet".

Additionally: IRSNB a13208 (Figs 8D, E, G), a13209 (Figs 8F, H), two cephala and IRSNB a13210 (Figs 8I, L), a13211 (Fig. $8 \mathrm{~J}$ ), two pygidia, from Loc088, Marloie; Ermitage Member of the Moulin Liénaux Formation.
Discussion. This species was described by Richter \& Richter (1926) on the basis of two pygidia in the collections of the IRSNB that come from middle Frasnian strata in Givet and Boussu-enFagne. Van Viersen \& Bignon (2011) examined cephala in the collections of the IRSNB which, according to their labels, had been identified as B. mosanus by the Richters but these were all poorly preserved. As far as they could be compared by us, the cephala and especially the pygidia from Marloie are indistinguishable from the types from Givet.

The material kept by the Universite de Liège from the Frasnian in the Hotton area and labelled "Cryphaeus valleeanus Dewalque" (a nomen nudum, as according to Asselberghs, 1912) was examined by AV and is possibly conspecific.

\section{Bradocryphaeus neptuni van Viersen \& Bignon, 2011}

Subspecies assigned. Bradocryphaeus neptuni neptuni; Bradocryphaeus neptuni hottonensis ssp. nov.; Bradocryphaeus neptuni ssp. A. 2011

Bradocryphaeus neptuni neptuni van Viersen \& Bignon,

(Figs 6L-Q, S, T; Fig. 7)

v e.p. * 2011 Bradocryphaeus neptuni van Viersen \& Bignon, pp. 115 , 116, pl. 3, fig. G, pl. 4, figs C-J [non pl. 3, fig. H = B. cf. laomedeia sp. nov.].

2014 B. neptuni; Bignon \& Crônier, p. 662.

New material. IRSNB a13169, cephalon (Figs 6L-N, Q; Fig. 7) and IRSNB a13170 (Figs 6O, P, S, T; Fig. 7), pygidium, from Loc011, Lompret; Boussu-en-Fagne Member of the Grands Breux Formation.
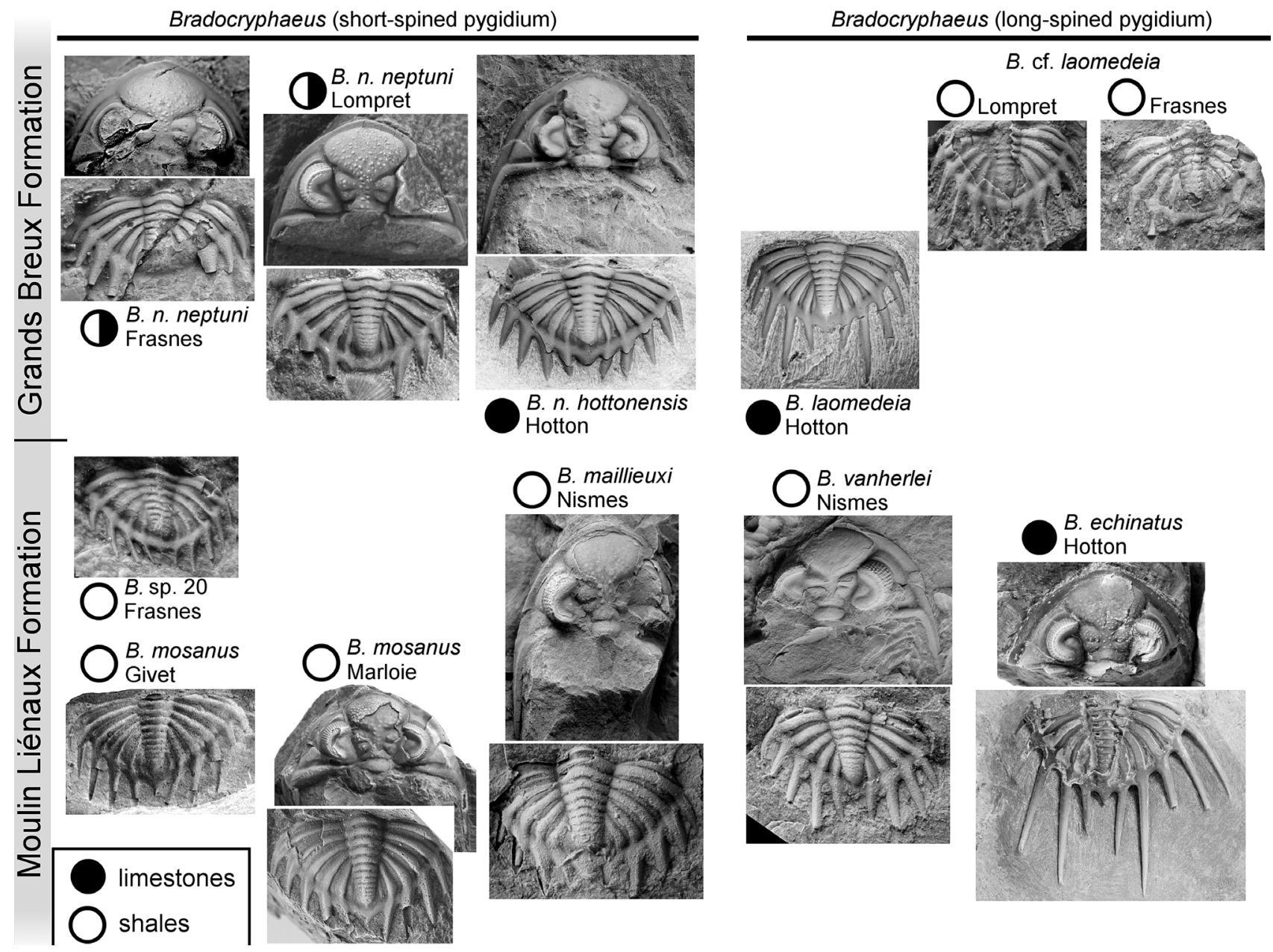

Figure 7. Morphological groups of Bradocryphaeus and their dominant facies occurrences in Belgium during the middle Frasnian. For a description of B. sp. 20 reference is made to van Viersen \& Bignon (2011). 

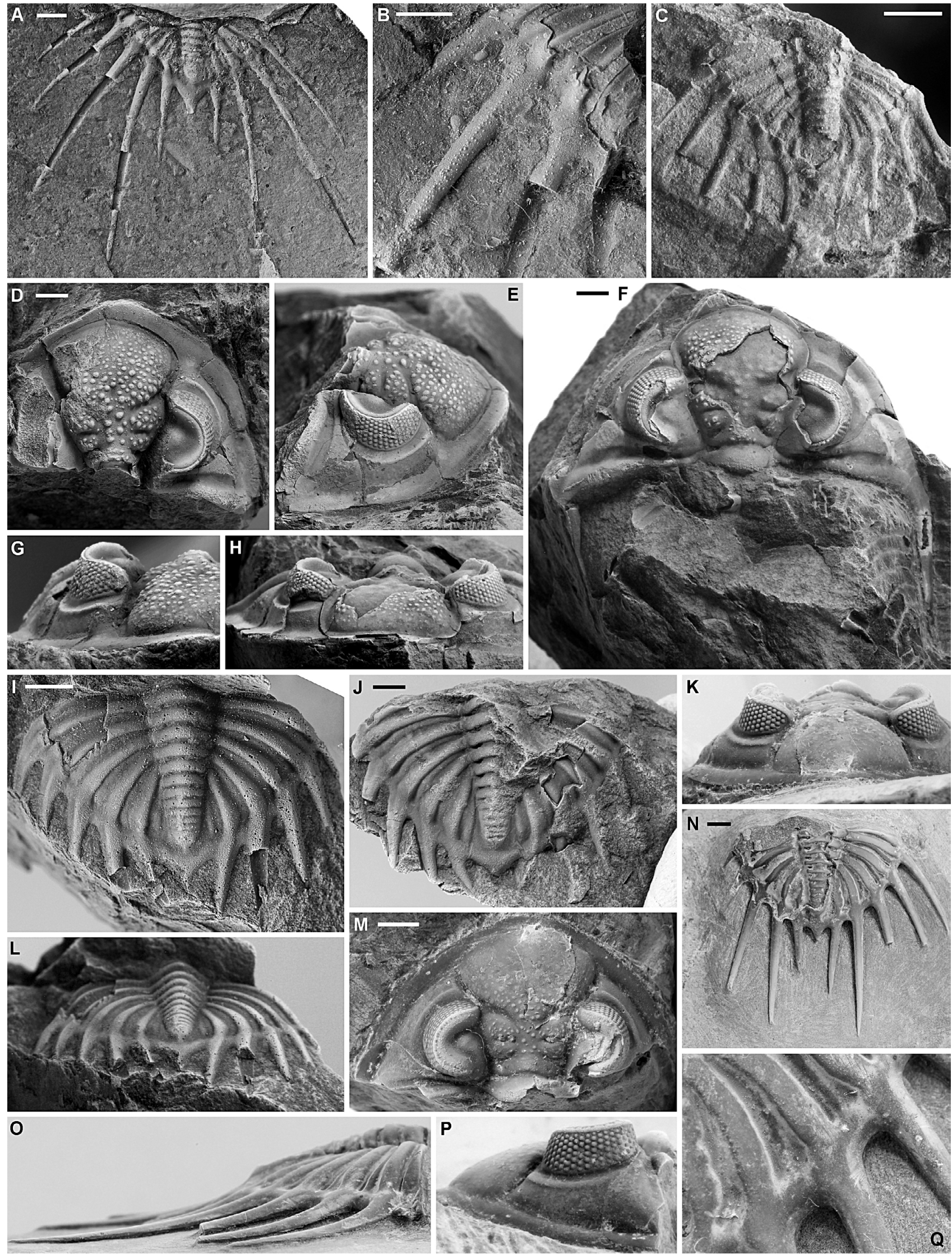

Figure 8. A, B. Heliopyge helios (Richter \& Richter, 1926) from the Ermitage Member of the Moulin Liénaux Formation at Loc018, Nismes. Incomplete pygidium, IRSNB a13166, in dorsal view (A). Fragment of left side of a pygidium, IRSNB a13167, in dorsal view (B).

C. Heliopyge cf. helios from the Bovesse Formation at Loc096, Ligny. Partially exfoliated pygidium, IRSNB a13188, in dorsal view.

D-J, L. Bradocryphaeus mosanus (Richter \& Richter, 1926) from the Ermitage Member of the Moulin Liénaux Formation at Loc088, Marloie. Cephalon, IRSNB a13208, in dorsal (D), oblique lateral (E) and anterior (G) views. Cephalon, IRSNB a13209, in dorsal (F) and anterior (H) views. Pygidium, IRSNB a13210, in dorsal (I) and posterior (L) views. Pygidium, IRSNB a13211, in dorsal view (J).

K, M-Q. Bradocryphaeus echinatus sp. nov. from the Ermitage Member of the Moulin Liénaux Formation at Loc120, Hotton. Holotype pygidium, IRSNB a13215, in dorsal (N), lateral (O) and close-up of right pleural field (Q) views. Paratype cephalon, IRSNB a13214, in anterior (K), dorsal (M) and lateral $(\mathrm{P})$.

All scale bars represent $2 \mathrm{~mm}$. 
Discussion. This subspecies was described by van Viersen \& Bignon (2011) for members of Bradocryphaeus from the limestones of the Grands Breux Formation in the vicinity of the Lion bioherm (Lion quarry near Frasnes). The new material from Lompret is indistinguishable except for the slightly less divergent axial furrows near L1 to anterior glabellar lobe and the maximum number of lenses per dorsoventral file in the visual surface (five, instead of seven in the holotype from Frasnes).

\section{Bradocryphaeus neptuni hottonensis ssp. nov.}

(Figs 5L, M, O, R, S; Fig. 7)

Etymology. After the type locality.

Holotype. IRSNB a13206, pygidium (Figs 5O, R, S; Fig. 7).

Paratype. IRSNB a13205, cephalon (Figs 5L, M; Fig.7), from type locality and horizon.

Type locality and horizon. Loc087, Hotton; Bieumont Member of the Grands Breux Formation.

Differential diagnosis. Posterior border furrow abaxial to eye is transverse. Narrow (tr.) glabella. Pygidium devoid of prosopon. Pygidial axial inter-ring furrows all (except for first) rudimentary medially so that an "axial median bridge" is developed. Pygidial pleural spines of broadly rounded section.

Discussion. Topotype material of the nominate subspecies from Frasnes is easily distinguished from the new subspecies through its wider (tr.) glabella, the posterior curvature of the posterior border furrow of cephalon as it runs abaxially towards the genal spine, the presence of granules on the pygidial axis and pleural spines, the well-developed pygidial inter-ring furrows, and the dorsally more angular section (tr.) of the pygidial pleural spines.

\section{Bradocryphaeus neptuni ssp. A}

(Figs 5E, J, K, N, Q)

Material. IRSNB a13187, nearly complete specimen (Figs 5E, K) and IRSNB a13185 (Fig. 5J), a13186, two pygidia (Figs 5N, Q), from Loc124, Mariembourg; Neuville Member of the Champ Broquet Formation.

Discussion. This is one of the stratigraphically highest members of Bradocryphaeus from Belgium. Despite a significant stratigraphic difference the pygidia are similar to topotype material of the nominate subspecies except, notably, for the more elevated pygidial pleural bands. The cephalon of our complete specimen is crushed and cannot be compared in detail.

\section{Bradocryphaeus laomedeia sp. nov.}

(Fig. 5P, Fig. 7)

Etymology. $\Lambda \alpha о \mu \varepsilon ́ \delta \varepsilon 1 \alpha$ (Greek; Laomedeia), a satellite of Neptune, referring to the occurrence of this species close to $B$. neptuni in certain localities.

\section{Holotype. IRSNB a13207, pygidium.}

Type locality and horizon. Loc087, Hotton; Bieumont Member of the Grands Breux Formation.

Diagnosis. Anterior two pygidial inter-ring furrows deepest, especially exsagittally; from there each consecutive furrow is shallower; sixth and following inter-ring furrows very narrow (exsag.). Six pairs of weakly curved pleurae which are devoid of sculpture. Anterior four pleural spine pairs are straight with slightly backward curved tips; rounded to somewhat keel-shaped in cross-section; each spine longer than the previous.

Description. Pygidium is smoothly rounded subtriangular; just over 1.5 times wider (tr.) than long (sag.). Axis comprised of 12 ( + terminal piece) axial rings, the first two of which are slightly anteriorly curved; the remaining rings are straightened (tr.). Axial furrows slightly more convergent posteriorly near anterior five rings than near remaining rings. First pleura is about 1.6 times longer than fifth. Proximal tip of fifth posterior pleural band reaches fifth axial ring. Posterior pleural bands are three times larger (exsag.) than anterior bands, extended onto pygidial border and extended into long, sword-shaped pleural spines. Fifth pleural spine pair is short, straight, convergent, and about as long as first spine pair. Terminal lappet rudimentary. Borders and spines are covered with densely-spaced, fine granules.

Discussion. The pygidia of B. neptuni and B. laomedeia from Hotton are similar at first sight except for the spine lengths. We might have been inclined to make a case for sexual dimorphism. Apart from practical issues to provide evidence for such a claim, the short-spined pygidium and the cephalon from Hotton are in turn similar to $B$. neptuni specimens from Frasnes and Lompret and assigned to a new subspecies, $B$. neptuni hottonensis. The long-spined pygidium from Hotton lacks distinctive features of this species, such as the broad (tr.), subtriangular pygidial outline and the proximal fenestrae. Consequently, we assign it to a new species, B. laomedeia. Long-spined pygidia similar to the one from Hotton have been recovered from the Boussu-enFagne Member of the Grands Breux Formation in Lompret and Frasnes. These are tentatively assigned to this same new species (see below).

Bradocryphaeus vanherlei van Viersen \& Bignon, 2011 from Nismes is easily distinguished through the shallower pygidial pleural and interpleural furrows, merely 10 pygidial axial rings, and the long fifth pygidial pleural spine pair (twice as long as associated pleurae). Specimens of B. vanherlei are usually also smaller. Bradocryphaeus laomedeia may well represent a broader group of comparatively large-sized species (compare, e.g. B. cf. laomedeia).

The type species, B. supradevonicus, comes from the Oos Formation (punctata to Upper rhenana Conodont zones) in Büdesheim-Oos in the Eifel. Topotype specimens were figured by Kowalski (1990, p. 50, fig. 42) and Basse (2003, pl. 27, figs 444455). Königshof et al. (2016, p. 40, fig. 6) recorded a cephalon and a pygidium from the Oos Formation in the Eifel (not the type locality) which they identified as B. supradevonicus. The cephalon has few, comparatively small tubercles, and the pygidial pleural pattern and spines are similar to those of Bradocryphaeus laomedeia sp. nov. We do not regard these specimens as belonging to $B$. supradevonicus but rather believe that they represent a new species.

\section{Bradocryphaeus cf. laomedeia sp. nov.}

(Fig. 6R, Fig. 7)

v e.p. 2011 Bradocryphaeus neptuni van Viersen \& Bignon, pp. 115, 116, pl. 3, fig. H.

New material. IRSNB a13171, pygidium, from Loc011, Lompret; Boussu-en-Fagne Member of the Grands Breux Formation.

Discussion. Along with the description of Bradocryphaeus neptuni van Viersen \& Bignon (2011) included a poorly preserved pygidium from the shales of the Boussu-en-Fagne Member at the type locality near Frasnes in their type series. The similarities of this pygidium to $B$. laomedeia suggest that it is closely related to that species instead. New collections from the Lompret quarry have yielded another similar pygidium from the Boussu-enFagne shales.

\section{Bradocryphaeus echinatus sp. nov.}

(Fig. 7; Figs 8K, M-Q)

Etymology. Echinatus (Latin; spiny), an understatement, in reference to the rather long pygidial spines.

Holotype. IRSNB a13215, pygidium (Fig. 7; Figs 8N, O, Q).

Paratype. IRSNB a13214, cephalon (Fig. 7; Figs 8K, M, P), from type locality and horizon. 
Type locality and horizon. Loc120, Hotton; Ermitage Member of the Moulin Liénaux Formation.

Diagnosis. Comparatively strongly vaulted (tr.) cephalon. Glabellar sculpture consisting of small tubercles restricted to central part. First pygidial pleural spine pair is twice as long as associated pleurae. Broad (exsag.) and deep pygidial pleural and interpleural furrows; without fenestrae.

Discussion. This species shares with stratigraphically slightly younger Bradocryphaeus vanherlei from Nismes, the weakly developed subocular ridge, comparatively fine sculpture on the glabella, dorsally low pygidial posterior pleural bands, and long fifth pygidial pleural spine pair. Bradocryphaeus vanherlei is discriminated by its shallower palpebral furrows, broader cephalic outline, rudimentary pleural and interpleural furrows, short first pygidial pleural spine pair and terminal spine.

Bradocryphaeus echinatus might be taken for a Heliopyge. However, this last genus is distinguished by its thinner, hardly tapered, longer pygidial pleural spines (especially third and fourth pair). Furthermore, the pygidium of Heliopyge is triangular in outline (with sharp angles), the axis hardly tapers posteriorly, exceedingly large fenestrae are developed, and the pleural spines are more outward instead of backward projected.

\section{Genus Quadratispina Gandl, 1972}

Type species. Neocalmonia (Quadratispina) quadratispinosa Gandl, 1972.

Diagnosis (translated from Gandl, 1972, with emendations). Occipital ring bearing a median tubercle. Pygidial axis comprising 10-13 (+1) narrow (sag.), sharply demarcated rings most of which bearing a median tubercle (weak or absent in posterior rings). 5-6 pairs of pleurae with a strongly modified supradevonicus pattern: these consist of steeply inclined posterior bands and moderately narrow (exsag.) yet sharply demarcated and individually vaulted anterior bands. The abaxial half of the posterior pleural band is often widened; in those cases it overhangs the anterior band of the posteriorly lying pleura; further abaxially the posterior pleural bands are extended as roof-shaped swellings on the pygidial border and into pleural lappets; border furrows at these transitional points nonetheless visible (indented). Interpleural furrows narrow and sharp. Large fenestrae may be developed. Pleural furrows equivalent to average width (exsag.) of a posterior pleural band; considerably deepened. Pleural lappets shorter than first pleural pair, lumpish, sharply keeled, and as a result subquadratical in section, always posteriorly directed, and at least the fifth pair convergent. Terminal lappet about as long as fifth pleural lappet; triangular.

Species assigned. Asteropyge (Asteropyge) hispanica Richter \& Richter, 1926 and Neocalmonia (Heliopyge) asturica Haas, 1970 from the Frasnian of Spain; Quadratispina excelsa sp. nov. Questionably also Neocalmonia (Heliopyge) caelata Haas \& Mensink, 1970 and Neocalmonia (Heliopyge) mariamae Farsan, 1981 from the Givetian (?) of Afghanistan; Heliopyge sohensis Ghobadi Pour, Popov, Hosseini, Adhamian \& Yazdi, 2013 from the Frasnian of Iran.

Discussion. Haas \& Mensink (1970) distinguished three subgenera of Neocalmonia Pillet, 1969 based on the number of pygidial pleural spines and the presence or absence of pygidial fenestrae. These are $N$. (Neocalmonia) (four spines; without fenestrae), $N$. (Heliopyge) (five spines; with fenestrae), and $N$. (Bradocryphaeus) (five spines; without fenestrae). Gandl (1972) added a fourth, $N$. (Quadratispina) (five spines; sometimes with fenestrae). According to Arbizu (1977), Quadratispina had been erected based on the keel-like morphology of the pygidial pleural spines. Like Haas \& Mensink (1970), Arbizu (1977) attributed major significance to the presence or absence of pygidial fenestrae. He noticed that Quadratispina included species with and without pygidial fenestrae and so he reasoned that these must belong to different subgenera of Neocalmonia. This led Arbizu (1977) to reject Quadratispina. Recently, however, van Viersen \& Bignon
(2011) demonstrated the presence of small pygidial fenestrae in some members of Bradocryphaeus (compare, e.g. Fig. 6O). Thus, this feature can no longer be used to typify Heliopyge.

Gandl (1972) underlined the importance of the shape of the pygidial pleural bands of Quadratispina. He pointed out similarities to Bradocryphaeus but claimed that even transitional species could be assigned to either taxon based on the strongly modified supradevonicus pygidial pleural pattern of the former. The phylogenetic analyses of Lieberman \& Kloc (1997) and Bignon \& Crônier (2014) did not support the usage of such patterns. Indeed, with the exception of the supradevonicus pattern the resulting groupings have been shown to be artificial. The conception that some occurrences of pygidial pleural patterns are the result of convergent evolution, however, does not disqualify them as phylogenetically informative characters. That is, we argue that the patterns may still be used to support lower taxonomic ranks, provided that they are homologous within that context.

Bignon \& Crônier(2014) noticed that all former Quadratispina species share median tubercles on the pygidial axial rings. These workers considered this feature to bear significance only at the species level and referred to their phylogenetic analysis to support their suggestion. However, only one former Quadratispina species, Asteropyge hispanica Richter \& Richter, 1926, was coded and this is not the type species. Consequently, the analysis of Bignon \& Crônier (2014) cannot be used to validate the synonymy of Quadratispina with Bradocryphaeus. Similarly to the case of pygidial fenestrae, we believe that median tubercles on the pygidial axial rings developed independently in several lineages of the Asteropyginae. In this respect it is important to note that none of the other Bradocryphaeus species assigned to that genus by Bignon \& Crônier (2014) show this feature.

We conclude that the combination of characters in Gandl's (1972) diagnosis is adequate to discriminate Quadratispina from similar genera. We emend the diagnosis by adding the putatively synapomorphic pygidial axial tubercles and large fenestrae in some species, and furthermore by the presence of a median occipital tubercle and a maximum of 13 (as against 12 reported by Gandl) pygidial axial rings. Lastly, we promote Quadratispina to generic rank which is in line with the general trend of treating asteropygines, including former subgenera of Neocalmonia, as distinct genera - at least until a closer affinity is corroborated.

Occurrence. Quadratispina is restricted to the limestones of the Bovesse Formation on the northern border of the Namur Basin. Basse (2003, pl. 27, figs. 459, 460) illustrated pygidia from the "Givetian or Frasnian near Nismes" in the collections of the Senckenberg Museum, that he assigned to Bradocryphaeus cf. hispanica (transferred herein to Quadratispina). We agree with this identification. Unfortunately, the geographic and stratigraphic origins of the Senckenberg specimens remain unknown.

\section{Quadratispina excelsa sp. nov. \\ (Figs 6A-K)}

1879 Cryphaeus arachnoideus, Goldf. sp.; Malaise, p. 34.

1888 Cryphaeus arachnoïdeus (sic); Dormal, p. 103.

1912 Cryphaeus punctatus; Asselberghs, pp. 38-40, pl. 6, figs 13-17.

e.p. 1926 Asteropyge (Asteropyge) hispanica Richter \& Richter, pp. 211-213 [only Émines (sic)].

e.p. 1927 Asteropyge (Asteropyge) hispanica R. et E. Richter; Maillieux, pp. 80, 83, pl. 4, fig. 7 [only Émine (sic)].

e.p. 1927 Asteropyge (Asteropyge) mosana R. et E. Richter; Maillieux, pp. 82, 83 [only Émine (sic)].

Etymology. Derived from excelsus (Latin; exalted).

Holotype. IRSNB a13195, pygidium (Figs 6A, C, D, I).

Paratypes. IRSNB a13196-a13199 (Figs 6B, E, F, J, K), a13201 (Fig. 6H), five cephala and IRSNB a13200 (Fig. 6G), pygidium, all from type locality and horizon.

Type locality and horizon. Loc123, Emines; Bovesse Formation. 
Diagnosis. Occipital ring bearing densely spaced, fine granules and a large median tubercle. Eye is high, comprising maximally eight lenses per dorsoventral file. Librigenal field is very steep abaxial to the eye. Prominent eye ridge bearing tubercles posteriorly (faint anteriorly). Outer part of cephalic border bears fine granules; otherwise smooth. Pygidium of rounded subtriangular outline; bearing numerous granules that are concentrated medially on the axial rings, posterior pleural ribs and pleural spines. Distinct median tubercles on the anterior eight pygidial axial rings. Six pairs of well-developed pygidial pleurae with rather large fenestrae.

Description. Cephalon is parabolic. Anterior border slightly deflected medially but without the development of an anterior ledge. Glabella is moderately weakly vaulted (sag., tr.); covered with rounded, swollen pustules.. Glabella anterior to S0 is as long (sag.) as wide (tr.); widest (tr.) adjacent to anterior extreme of librigenal field. Axial furrows moderately deep, diverging throughout but curved around lateral glabellar lobes. S0 is narrow (sag., exsag.); S1 short and slightly curved; S2 straight (tr.) and abaxially shallow; S3 gently curved. Occipital ring is about as wide (sag.) as glabella across L1 (tr.), ascending high above the rest of the glabella; L1 is rudimentary; L2 and L3 are moderately strongly inflated and as high as central part of glabella. Expressively angular frontal glabellar lobe smoothly dropping in height towards anterior border; well-demarcated anteriorly and laterally by distinct grooves. Maximum width (tr.) of palpebral lobe is about 1.4 times that of L3. Lateral border is dorsally flattened. Lateral border furrow is shallow. Posterior border runs subtransversely. Genal spines are moderately long (less than sagittal length of cephalon) and thin.

Pygidium is parabolic to slightly subtriangular; on average 1.3 times wider (tr.) than long (sag.). Posteriorly slightly tapering, moderately low axis comprised of 13 axial rings (one of the pygidia figured by Asselberghs, 1912, appears to have 14), the first six of which are medially anteriorly curved; the remaining rings are straightened (tr.) and demarcated by distinct, straight, groove-like furrows. First pleura is about 1.3 times longer than fifth. Proximal tip of fifth pleura reaches fifth axial ring. Posterior pleural bands are much larger (exsag.) than anterior bands distally, extended onto pygidial border and continue as pleural spines. First, second and fifth pleural spine pairs are short. Third pleural spine is as long as third posterior pleural band; straight; slightly abaxially directed. Fourth pleural spine is as thick as third and clearly longer; running subexsagitally. Terminal lappet is short, acuminate and triangular. Borders and spines are covered with densely-spaced, coarse granules.

\section{Genus Heliopyge Haas \& Mensink, 1970} 1926.

Type species. Asteropyge (Comura) helios Richter \& Richter,

Occurrence. Members of this genus are confined to the Ermitage Member of the Moulin Liénaux Formation in Nismes and the Bovesse Formation in Ligny.

\section{Heliopyge helios (Richter \& Richter, 1926) (Figs 8A, B)}

New material. IRSNB a13166, external mould of a pygidium (Fig. 8A) and IRSNB a13167 (Fig. 8B), pygidial fragment, from Loc018, Nismes; Ermitage Member of the Moulin Liénaux Formation.

Discussion. The cephalon of this species was redescribed by van Viersen \& Bignon (2011) because Richter \& Richter (1926) had based their illustrations and descriptions on a juvenile specimen. Two partial pygidia from the Moulin Liénaux Formation in Nismes are recorded here that show the distinctive length and shape of the pleural spines.

Heliopyge cf. helios (Richter \& Richter, 1926)

(Fig. 8C)
Material. IRSNB a13188, pygidium, from Loc096, Ligny; Bovesse Formation.

Discussion. This pygidium is not well preserved but shows important similarities to Heliopyge helios from Nismes such as the triangular pygidial outline and the long, hardly tapered pleural spines of rounded section, the first pair of which is very thin. The axis seems to be broader (tr.) than that of H. helios and the terminal lappet is acuminate but spineless. Therefore, the specimen is provisionally designated $H$. cf. helios.

Family Scutelluidae Richter \& Richter, 1955

Subfamily Scutelluinae Richter \& Richter, 1955

\section{Genus Torleyiscutellum Basse, Koch \& Lemke, 2016}

Type species. Scutellum (Scutellum) torleyi Archinal, 1994, from the Givetian of the Rhenish Mountains.

Species assigned. See Basse et al. (2016).

Discussion. Torleyiscutellum encompasses taxa formerly included in Scutellum Pusch, 1833. Basse et al. (2016) restricted Scutellum to its type species, S. costatum Pusch, 1833, because the latter is ambiguous and, in all probability, cannot be salvaged. A similar, less ideal solution was given by van Viersen (2015) who proposed a transfer of former Scutellum species to Goldius De Koninck, 1841. Differences between Goldius and Torleyiscutellum were described by Basse et al. (2016).

Occurrence. Members of Torleyiscutellum occur associated with mounds in the Moulin Liénaux, Grands Breux and Champ Broquet formations. Further specimens come from the biostromal limestones in the lower part of the Philippeville Formation.

\section{Torleyiscutellum spp.}

(Figs 9A-Y, 10A, B)

Material. Dinant Synclinorium: IRSNB a13212a $+\mathrm{b}$ (= Torleyiscutellum sp. G; Figs 9L-O), from Loc011, Lompret, Grands Breux Formation, Lion Member; IRSNB a13193 (= Torleyiscutellum sp. H; Fig. 9P), from Loc090, Ny, Fromelennes or Nismes formations; IRSNB a13182 (= Torleyiscutellum $\mathrm{sp}$. E; Figs 9V, W), from Loc92, Surice, Grands Breux Formation, Lion bioherm; IRSNB a13179, a13180, a13191 (= Torleyiscutellum sp. I; Figs 9U, X, Y), from Loc093, Han-sur-Lesse, Grands Breux Formation, Lion Member. IRSNB a13202-a13204, a13176a13178 (= Torleyiscutellum sp. X; Figs 9D, E, G-K), from 043, Frasnes, Grands Breux Formation, Lion Member.

Philippeville Anticlinorium: IRSNB a13168, a13174, a13175 (= Torleyiscutellum sp. A; Figs 9A, C, F), from Loc89, Neuville, Champ Broquet Formation, Petit-Mont Member; IRSNB a13172, a13173 (= Torleyiscutellum sp. B; Figs 10A, B), from Loc125, Solre St. Géry, lower part of Philippeville Formation; IRSNB a13189, a13189, a13190 (= Torleyiscutellum sp. C; Figs 9Q-T), from Loc121, Senzeilles, lower part of Philippeville Formation; IRSNB a13192 (= Torleyiscutellum sp. D; Fig. 9B), from Loc122, Vodecée, Champ Broquet Formation, Petit-Mont Member.

Namur Basin: specimens figured by Asselberghs (1912, p. 38, pl. 5, fig. 12a, b), not examined (= Torleyiscutellum sp. F), from Loc123, Emines, Bovesse Formation.

Discussion. Van Viersen \& Prescher (2011) described two new species, Torleyiscutellum decipulum (Arche Member, Loc051, Frasnes) and Torleyiscutellum protrusifrons (Lion Member, Loc037, Boussu-en-Fagne), which had been identified previously as Scutellum costatum by Richter \& Richter (1926). No new material of either species was discovered in the meantime. The identifications of Torleyiscutellum specimens from other localities in Belgium have proved rather difficult and the current provisional assignments to this genus were based on similarities to the two earlier described species. Most of our material comes from Lion or Petit-Mont type mounds but exact origins within the mounds are not known. The specimens are often also incomplete, making it difficult to compare them. 

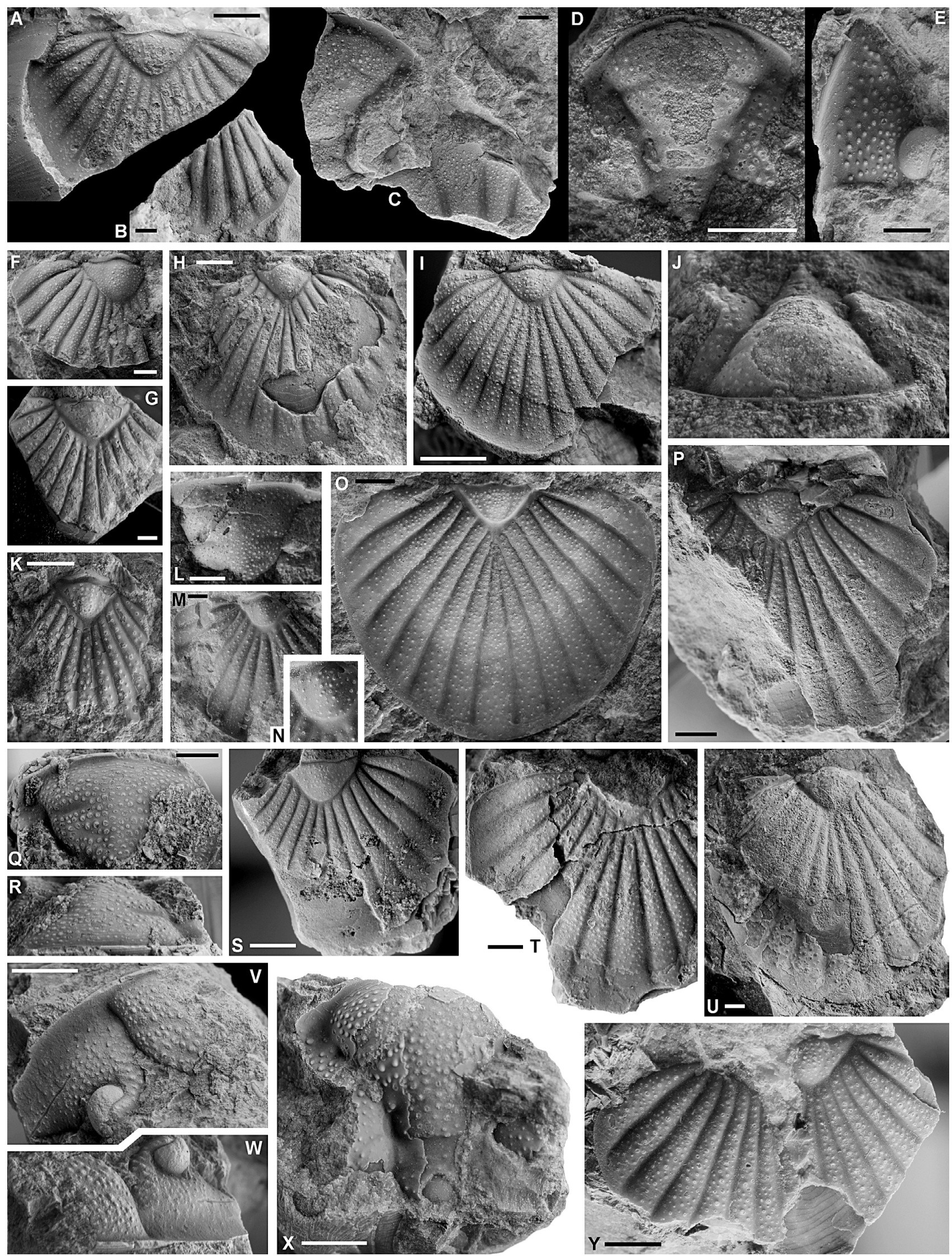

Figure 9. A, C, F. Torleyiscutellum sp. A from the Petit-Mont Member of the Champ Broquet Formation at Loc89, Neuville. Incomplete pygidium, IRSNB a13168, in dorsal view (A). Fragmentary cranidium and pygidium, IRSNB a13174, in dorsal view (C). Fragmentary pygidium, IRSNB a13175, in dorsal view (F).

B. Torleyiscutellum sp. D from the Petit-Mont Member of the Champ Broquet Formation at Loc122, Vodecée. Fragmentary pygidium in dorsal view.

D, E, G-K. Torleyiscutellum sp. X from the Lion Member of the Grands Breux Formation at Loc043, Frasnes. Holaspid cranidium, IRSNB a13202, in dorsal (D) and anterior (J) views. Librigena, IRSNB a13203, in dorsal view (E). Fragmentary pygidium, IRSNB a13178, in dorsal view (G). Pygidium, IRSNB a13176, in dorsal view (H). Pygidium, IRSNB a13177, in dorsal view (I). Fragmentary pygidium, IRSNB a13204, in dorsal view (K).

L-O. Torleyiscutellum sp. G from the Lion Member of the Grands Breux Formation at Loc011, Lompret. Incomplete external mould of a cranidium, IRSNB a13212b, in dorsal view (L). Incomplete pygidium, IRSNB a13213, in dorsal view (M) and close-up of axis (N). Pygidium with anomalous (short) median rib ceasing well before reaching axis, IRSNB a13212a, in dorsal view (O).

P. Torleyiscutellum sp. H from the Fromelennes or Nismes formations at Loc090, Ny. Incomplete pygidium, IRSNB a13193, in dorsal view.

Q-T. Torleyiscutellum sp. C from the lower part of the Philippeville Formation at Loc 121, Senzeilles. Fragmentary cranidium, IRSNB a13181, in dorsal (Q) and anterior (R) views. Incomplete pygidium, IRSNB a13189, in dorsal view (S). Incomplete pygidium, IRSNB a13190, in dorsal view (T).

U, X, Y. Torleyiscutellum sp. I from the Lion Member of the Grands Breux Formation at Loc093, Han-sur-Lesse. Pygidium, IRSNB a13191, in dorsal view (U). Incomplete cranidium, IRSNB a13179, in dorsal view (X). Fragmentary pygidium, IRSNB a13180, in dorsal view (Y).

V, W. Torleyiscutellum sp. E from the Lion Member of the Grands Breux Formation at Loc092, Surice. Fragmentary cephalon, IRSNB a13182, in dorsal (V) and anterior (W) views.

All scale bars represent $3 \mathrm{~mm}$ 

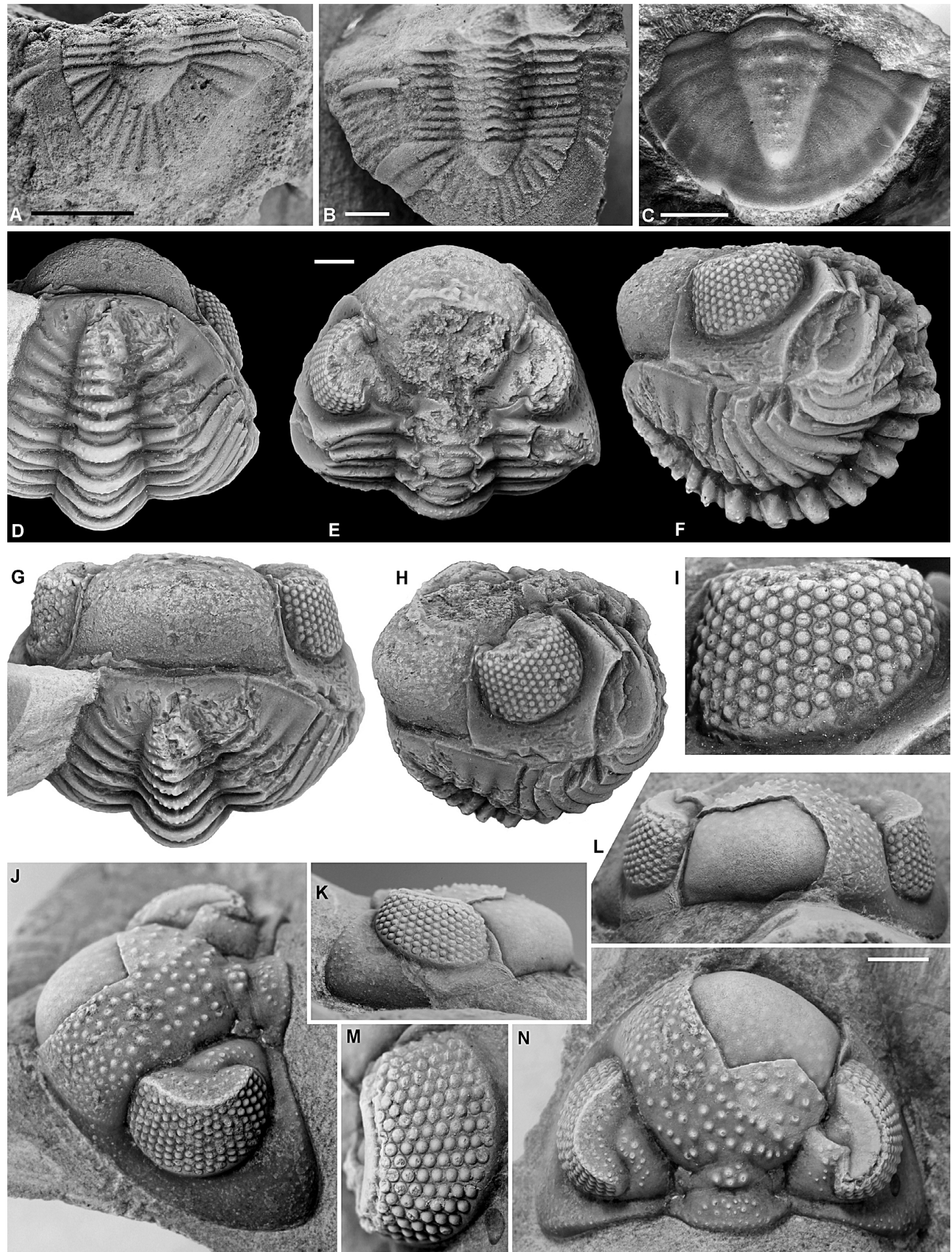

Figure 10. A, B. Torleyiscutellum sp. B from the lower part of the Philippeville Formation at Loc125, Solre St. Géry. Partial thoracopygidium, IRSNB a13172, in dorsal view (A). Articulated specimen with fragmentary cephalon and pygidium, IRSNB a13172, in dorsal view (B).

C. Pterocoryphe platymarginata sp. nov. from the Petit-Mont Member of the Champ Broquet Formation at Loc095, Mariembourg. Holotype external mould of a pygidium, IRSNB a13194, in dorsal view (digitally inverted image).

D-I. Magreanops renateae sp. nov. from the Ermitage Member of the Moulin Liénaux Formation at Loc120, Hotton. Holotype enrolled specimen, IRSNB a13216, in dorsal view of pygidium (D), dorsal view of cephalon (E), lateral (F), anterior (G), oblique anterolateral (H) and close-up of eye (I) views.

J-N. Magreanops monachus sp. nov. from the Bovesse Formation at Loc094, Golzinne. Holotype cephalon, IRSNB a13217, in dorsolateral (J), lateral $(\mathrm{K})$, anterior $(\mathrm{L})$, close-up of right eye $(\mathrm{M})$ and dorsal $(\mathrm{N})$ views.

All scale bars represent $2 \mathrm{~mm}$. 
Further complicating are moderate morphological variations and fairly common pathologies. These often affect the pygidial median rib (see, e.g. Fig. 90), an important marker used in the discrimination between species. All these factors hinder the definitions of species boundaries. It is conceivable that different types of mounds and even various mound growth stages can be associated with different species. Consequently, we have decided to treat the specimens from each of our localities as individual species, in open nomenclature, until more material and accurate data on stratigraphy and palaeoecology become available. Stratigraphic ranges are extended for each species in Figure 4 as assumed to occur in the entire mound, at least until known to be otherwise (e.g. T. protrusifrons).

Of note are the small eyes of Torleyiscutellum spp. and Torleyiscutellum protrusifrons from the Lion mounds in comparison to Torleyiscutellum decipulum from the stratigraphically older Arche mounds. Eye size reduction has been recognised in various phyletic lineages of Late Devonian trilobites worldwide, including scutelluids (Feist, 1995; McNamara \& Feist, 2016).

Family Phacopidae Hawle \& Corda, 1847

Subfamily Phacopinae Hawle \& Corda, 1847

\section{Genus Magreanops nov.}

Etymology. Named after Benedikt Magrean who found the holotype of the type species and donated it for study. Gender masculinum.

\section{Type species. Magreanops renateae gen. \& sp. nov.}

Diagnosis. Moderately small phacopid. Cephalon parabolic in outline, bearing widely spaced, cone-like pustules on glabella. Dorsoventrally low occipital ring. L1 small, flat, sunken deep below adjacent parts of the cephalon. Moderately broad palpebral area, highest point slightly ascending above palpebral lobe. Anterior half of glabella more inflated than posterior half. Lateral glabellar furrows S2 and S3 and post- and subocular pads absent. Axial furrow rudimentary anterior to eyes. Narrow glabella, with axial furrows more divergent between $\mathrm{S} 1$ and point opposite $\delta$ than anterior to this last point. Large visual surface (max. 18/89 lenses); sclera not developed horizontally between lenses and rudimentary between dorsoventral files of lenses; lenses distinctly protruding from visual surface. Short (sag., exsag.) thoracic axial rings, bearing close-set tubercles anteriorly and few tubercles posteriorly; weakly defined lateral lobes. Pygidial axial rings bearing closely spaced tubercles; first three inter-ring furrows are particularly well developed. Pygidial pleurae bearing few small tubercles; pleural furrows broad (exsag.) and deep.

\section{Species assigned. Magreanops monachus gen. \& sp. nov.}

Discussion. As stated below (see 5.3.), Magreanops is unique in that it is the first large-eyed phacopid to be recorded from Frasnian strata worldwide. It bears similarities to species from the Ardenno-Rhenish Mountains currently included in the problematic Pedinopariops Struve, 1972 (see Basse, 2006). The stratigraphically youngest of these species stem from the earliest Givetian. Setting aside the huge stratigraphic gap between members of both genera, the similarities are probably superficial and mostly related to the large eyes, a trait shared by a number of other phacopid genera (see van Viersen et al., 2017). The type species of Pedinopariops, P. lentigifer (Struve, 1970) from the Eifelian in the Eifel, differs in important aspects such as the inflated and isolated L1 and intercalating ring, firmly impressed lateral glabellar furrows, gradually anteriorly descending glabella (sagittal section) with more densely spaced and larger tubercles, axial furrows that are divergent anterior to S2, welldeveloped posterior pads, broad and deep lateral border furrow, dense sculpture consisting of tubercles and pits on the lateral and posterior borders, less tightly packed lenses in the visual surface as a result of thicker sclera.

Furthermore reminiscent of Magreanops is Eldredgeops Struve, 1990 from the Givetian in the USA (putative Frasnian occurrences have been reported but these were never described). The contents of Eldredgeops is subject to revision. Commonly included taxa are E. milleri (Stewart, 1927) (the type species), E. rana (Green, 1832) and E. crassituberculata (Stumm, 1953). Yet even if Eldredgeops was to be restricted to these species the morphologic disparity would still be vast and the genus clearly be polyphyletic. McKellar \& Chatterton (2009) performed a broad cladistic analysis on Devonian phacopids that cast doubt upon the independent generic rank of Eldredgeops. However, their conclusion cannot be sustained since they inadvertently took $E$. rana for the type species and coded that for analysis instead of $E$. milleri. These two species are rather dissimilar and likely belong to different genera. Babcock (1992) noticed that the type series of E. milleri consists of multiple species and selected a complete, partially enrolled specimen as the lectotype. This specimen is principally different from our Magreanops material in having a widely rounded cephalon, isolated L1, firmly impressed lateral glabellar furrows, gradually anteriorly descending glabella bearing large, closely spaced, flattened tubercles and without anterior overhang, presence of posterior pads, wide, weakly vaulted (tr.) thoracic and pygidial axes with long (sag., exsag.) robust rings, pygidium lacking pronounced tubercles, and narrow pygidial inter-ring and pleural furrows.

\section{Magreanops renateae gen. \& sp. nov. (Figs 10D-I)}

v 2014 Phacopinae gen. et sp. indet.; Magrean \& Taghon, p. 26, fig. 5 .

e.p. 2015 Phacopinae indet.; van Viersen, p. 9 [Frasnian].

\section{Etymology. Named after Renate Magrean.}

Holotype. IRSNB a13216, partially exfoliated complete specimen (Figs 10D-I).

Type locality and horizon. Loc120, Hotton; Ermitage Member of the Moulin Liénaux Formation.

Diagnosis. Genal tip reaching backward until lateral of second thoracic axial ring. Well-developed posterior border furrow. Strongly vaulted (tr.), compacted (sag., tr.) cephalon. Glabella anterior to eyes short (sag., exsag.) and with distinct overhang. Visual surface comprising 18 dorsoventral files with maximally 9 lenses per file.

\section{Magreanops monachus gen. \& sp. nov. \\ (Figs 10J-N)}

e.p. 2015 Phacopinae indet.; van Viersen, p. 9 [Frasnian].

Etymology. Derived from "a monk's work" (monachus, Lat.; monk), a common regional expression, in reference to the surprisingly challenging preparation performed by F. Lerouge.

Holotype. IRSNB a13217, cephalon (Figs 10J-N).

Type locality and horizon. Loc094, Golzinne; Bovesse Formation.

Diagnosis. Genal tip reaching backward until lateral of occipital ring. Shallow posterior border furrow. Glabella with slight anterior overhang; bearing widely spaced cone-shaped tubercles. Visual surface comprising 18 dorsoventral files with maximally 8-9 lenses per file. Intercalating ring only accentuated by the presence of several densely spaced pustules.

Discussion. The cephalon of M. monachus from Golzinne and the enrolled specimen of $M$. renateae from Hotton are both well preserved (not tectonically deformed) in spite of having abraded or exfoliated patches. They are similar as far as they can be compared yet clearly differ in several important aspects: M. monachus has a less posteriorly projected genal angle, a shallower posterior border furrow, larger, less downward-tilted eyes but with slightly fewer lenses, elongated glabella projecting 
further anteriorly beyond the eyes and with less anterior overhang (compare Fig. 10F to Fig. 10K). These differences warrant the descriptions of both species awaiting the discovery of additional material.

\section{Origin and palaeogeographic relationships of the Belgian Frasnian trilobite fauna}

Van Viersen (2015) recognised three intervals of increased trilobite "immigrations" in Belgium during the Devonian (Fig. 3), referring to the influx of "Hercynian" elements known to occur in older strata elsewhere in the world. The first wave commenced in the late half Pragian and is characterised by the onset of such "Hercynian" trilobites in the offshore facies of the Villé Formation (Neufchâteau Synclinorium). A second, very uncertain wave started in the upper Emsian: it corresponds to the putative acme of the Daleje Event (Hierges Formation), adding "Hercynian" elements to trilobite associations on the southern border of the Dinant Synclinorium and followed by other "Hercynian" taxa along with extensive carbonate production (St. Joseph-Eau Noire complex). The final wave started in the basal Frasnian and is characterised by the widespread deposition of shales and the appearance of Bradocryphaeus.

As shown above, the Frasnian trilobite fauna of Belgium is best characterised as generally coherent, with scutelluids dominating the reefal environments and acastids in the lateral facies. With each major T-R cycle an alternative of this "base" trilobite fauna was installed. Taxa accentuating these alternatives are probably primarily allochthonous elements. Trilobite genera shared between Belgium, other parts of southern Laurussia and (peri-)Gondwanan terranes during the Frasnian are shown in Figure 11

\subsection{Acastidae}

Bradocryphaeus is palaeogeographically widely distributed owing much of its radiation to eustatic sea level rises that commenced in the Givetian (Morzadec, 1992). According to the revised definition of Bignon \& Crônier (2014) (but see remarks

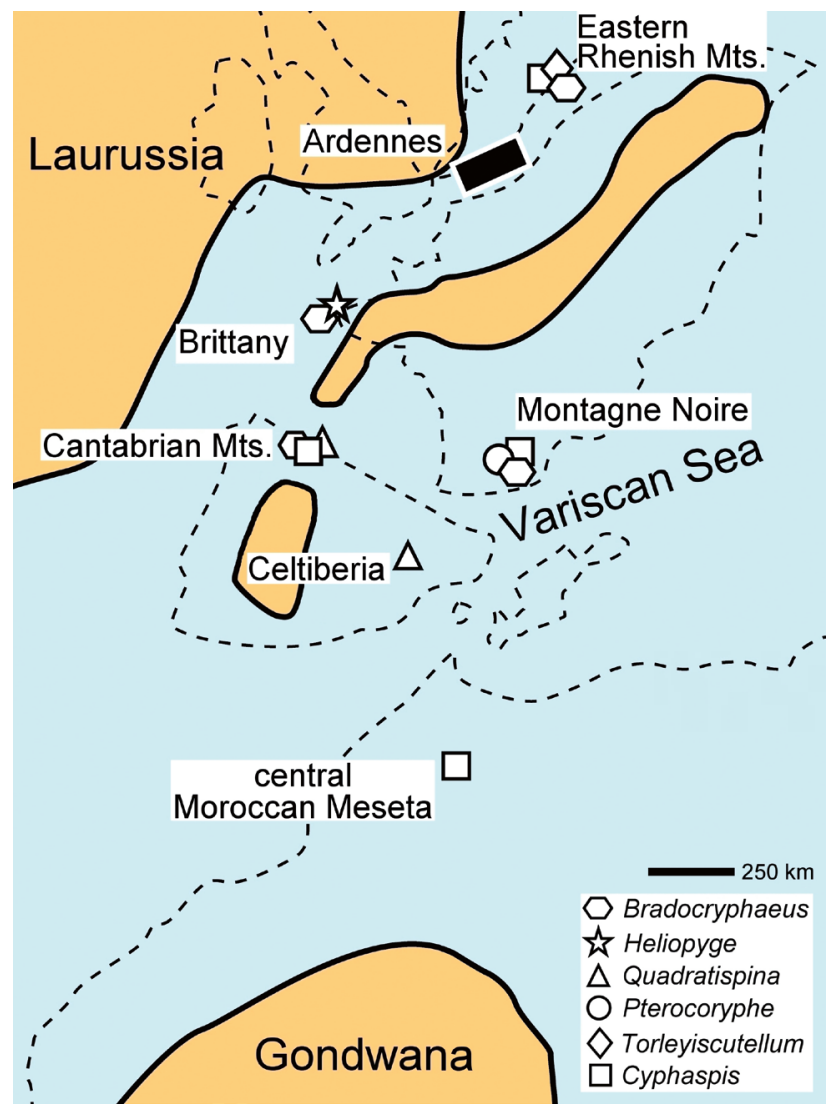

Figure 11. Palaeogeographic map of western Europe and northwest Africa during the Frasnian. Adopted from Dopieralska et al. (2016, fig. 1) with modifications. The Ardennes, including western part of the Eifel, is indicated by a black rectangle. in taxonomic section herein) Bradocryphaeus species occur in the Givetian of Brittany, the Cantabrian Mountains, eastern Iran, western Afghanistan and in the Frasnian of Brittany, the Boulonnais, Ardennes, Eifel, Cantabrian Mountains and eastern Iran. We add to that the occurrence of Bradocryphaeus in the Givetian of the Right Rhenish Mountains (Basse, 2003). Members of this genus are specialists of shaly sediments. They are chief components of the Frasnian "base" trilobite fauna of Belgium and in all probability settled here during regional Frasnian T-R cycle 1 , for they are not known from the Givetian carbonate platform nor would there have been many suitable habitats. Phylogenetic affinities between Bradocryphaeus species worldwide remain unclear and even within Belgium the diversity is significant. The demise of the Asteropyginae including Bradocryphaeus was studied by Morzadec (1992) who suggested that the terrigenic detritic deposits triggered by tectonic uplift in Belgium were unfavourable for its members. This is not confirmed by our data which suggest that various lineages continued, with relative success, until levels just below the first darkening of the sediments in the Dinant Synclinorium (i.e. close to the Lower Kellwasser level).

Heliopyge is known outside Belgium only in Brittany where Morzadec (1983) recorded Heliopyge aff. helios from the upper Frasnian Rostiviec Formation. Bignon \& Crônier (2014) pointed out that the pleural fields of the French material are not well preserved, impeding the recognition of the pleural pattern and consequently, assignment to a genus. However, the combination of a triangular pygidial outline, narrow pygidial axis, and long, hardly tapered pygidial pleural spines strongly suggests that it is a Heliopyge.

Quadratispina is known outside Belgium only from the Frasnian in Spain but those occurrences are not very precisely dated.

The distribution of these acastids in southern Laurussia and peri-Gondwanan terranes points to open, shallow-water migration routes between these continents during the Frasnian.

\subsection{Scutelluidae}

Scutelluid morphological disparity in the Belgian Frasnian is rather limited. Only the conservative Torleyiscutellum occurs here which evolved, with few changes, from a Givetian rootstock. Palaeogeographically this genus was confined to the southern margins of Laurussia. Feist (1974) recorded Scutellum gallicum from the Frasnian of the Montagne Noire but according to Basse et al. (2016) the generic affinity of that species remains uncertain.

\subsection{Phacopidae}

Phacopids (e.g. Cryphops, Acuticryphops, Nephranops) have been recorded from Frasnian sections in Germany, France, Morocco and NW Australia but all of these are atheloptic. In fact, we could not find any substantiated published record of a big-eyed phacopid from post-Givetian strata, except for the latest Famennian Omegops Struve, 1976. Chlupáč (1993) recorded a large-eyed phacopid from the Givetian-Frasnian transitional (lower Szydłówek) beds in the Holy Cross Mountains that he described as Chotecops zofiae. Although the age of the Szydłówek Beds is not well defined, conodont data from the lower part suggest a latest Givetian age (Racki \& Bultynck, 1993). Smeenk (1983) illustrated large-eyed phacopids from the putatively lower Frasnian Portilla Formation and basal part of the overlying Nocedo Formation in Spain, which he assigned to various species of Phacops Emmrich, 1839. Van Loevezijn (1988) added that Smeenk's Phacops rana aff. rana in particular, is a common species in the transitional beds between these formations. According to the more recent chronostratigraphy of Fernández et al. (1997), however, these strata are all of Givetian age. Thus it appears that the middle Frasnian Magreanops is a world novelty.

According to Feist (1995) phacopid eye reduction is a universal and unidirectional trend that occurred in several lineages throughout the Givetian to Famennian. The appearance of members of Magreanops in the middle Frasnian of Belgium suggests that evolution of big-eyed phacopids took place in settings not exposed at present. The distribution of shallow-water environments to which Devonian trilobites were confined was 
limited during the Late Devonian and so could their preservational potential in the geological record be expected to be reduced (Owens, 1994). Open migration routes between Armorica, the Celtiberian-Cantabrian domain and southern Laurussia as demonstrated by other trilobite groups along with Late Givetian records of big-eyed phacopids, suggest that early Frasnian strata to potentially bear ancestors of Magreanops, might be sought in western Europe.

\subsection{Proetidae}

Members of the Dechenellinae are known from strata up to Middle Givetian age in Belgium (Bignon \& Crônier, 2015), the Rhenish Mountains (Struve, 1992; Basse, 2002) and Poland (Chlupáč, 1993). Dechenella was furthermore reported by Lombard (1952) from the middle Alvaux Member of the Bois de Bordeaux Formation (Givetian) which underlies the Bovesse Formation in the same area that the pygidia illustrated by Asselberghs (1912, pl. 6 , figs 18,19$)$ came from. It seems possible that Dechenellinae persisted in Belgium from the Eifelian, throughout the Givetian, into the Frasnian.

According to Feist (2003) tropidocoryphids (included in proetids herein) were exclusive to the Montagne Noire during the Late Givetian to middle Frasnian; they were terminated at the Upper Kellwasser level. Pterocoryphe is a Lazarus taxon. It was perceived to range from the falsiovalis to hassi Conodont zones. Thus, it ended in the middle Frasnian, well before reaching the upper Frasnian. The discovery of a pygidium in the Lower rhenana Conodont Zone in Belgium is remarkable in several ways. Not only does the genus reappear after a substantial gap in the fossil record but also a member managed to find safe passage from peri-Gondwana to the outer margin of Laurussia and invade a new habitat without showing major morphological (at least pygidial) changes.

\subsection{Harpetidae}

A fragmentary harpetid cephalon was identified in the lateral facies of the Grands Breux Formation (Couvin area) but remains in a private collection (see van Viersen \& Bignon, 2011). The genus could not be resolved and so a comparison to harpetids from other regions cannot be made. This occurrence was therefore omitted from the palaeogeographic map. Harpetids are characteristic components of Frasnian sections worldwide.

\subsection{Aulacopleuridae}

Cyphaspis is a geographically and stratigraphically widely distributed genus. It has been recorded from the Upper rhenana to linguiformis Conodont zones in Germany, France, Morocco and NW Australia. Other putatively Late Devonian records come from the USA, China and the Urals. Most of our specimens come from middle Frasnian strata; they predate the widely distributed Cyphaspis stigmatophthalmus of late Frasnian age. Instead, the Belgian specimens are more similar to Cyphaspis ibergia from Germany. A single cephalon of Cyphaspis sp. F from the upper Frasnian is perhaps closely related to C. stigmatophthalmus.

\section{Acknowledgements}

A. Folie and A. Drèze facilitated the study of trilobites in the old collections of the IRSNB with unflagging endurance. S. Goolaerts, M. Coen-Aubert and M. De Ceukelaire helped to trace information about several old localities. R. Speijer shared information on the collections of the Katholieke Universiteit Leuven. R. Endels, S. Goolaerts, I. Kesselaer, D. Lelubre, F. Lerouge, B. Magrean, P. Taghon and R. Walter donated trilobite specimens for study and/or communicated important field observations. R.T. Becker provided valuable suggestions on Devonian palaeogeography. The manuscript benefited from the review comments provided by M. Basse and A. Bignon.

\section{References}

Adrain, J.M. \& Chatterton, B.D.E., 1994. The aulacopleurid trilobite Otarion, with new species from the Silurian of northwestern Canada. Journal of Paleontology, 68, 305-323. https://doi.org/10.1017/ S0022336000022903
Arbizu, M., 1977. Asteropyginae (Trilobita) du Dévonien des Montagnes cantabriques (Espagne). Bulletin de la Société géologique et minéralogique de Bretagne (C), 9, 59-102.

Asselberghs, E., 1912. Description d'une faune frasnienne inférieure du bord nord du bassin de Namur. Bulletin de la Société belge de Géologie, de Paléontologie et d'Hydrologie, 26, 1-47.

Asselberghs, E., 1914. Observations sur le Frasnien des environs d'Hotton (bord oriental du bassin de Dinant). Bulletin de la Société belge de Géologie, de Paléontologie et d'Hydrologie, 28, 47-56.

Babcock, L.E., 1992. Lectotype of Phacops rana milleri Stewart, 1927 (Trilobita, Devonian of Ohio). Journal of Paleontology, 66, 692-693. https://doi.org/10.1017/S0022336000024604

Bambach, R.K., Knoll, A.H. \& Wang, S.C., 2004. Origination, extinction, and mass depletions of marine diversity. Paleobiology, 30, 522-542. https://doi.org/10.1666/0094-8373(2004)030<0522:OEAMDO >2.0 .CO;2

Barchy, L. \& Marion, J.-M., 1999. Carte géologique de Wallonie : Chimay - Couvin 57/7-8. 1/25 000. Namur, Ministère de la Région wallonne, Direction générale des ressources naturelles et de l'environnement, avec une notice explicative de $89 \mathrm{p}$.

Basse, M., 2002. Eifel-Trilobiten. 1. Proetida. Goldschneck-Verlag, Korb, $152 \mathrm{p}$.

Basse, M., 2003. Eifel-Trilobiten 2. Phacopida 1. Goldschneck-Verlag, Korb, $198 \mathrm{p}$.

Basse, M., 2006. Eifel-Trilobiten IV. Proetida (3), Phacopida (3). Quelle \& Meyer-Verlag, Wiebelsheim. 304 p.

Basse, M., Koch, L. \& Lemke, U., 2016. Torleyiscutellum herwigorum n. gen., n. sp. (Trilobita) from the Upper Honsel Beds of the northwestern Sauerland (Lower Givetian, Rhenohercynian Zone), with a contribution to scutelluid systematic. Neues Jahrbuch für Geologie und Paläontologie, Abhandlungen, 281, 51-93. https://doi. org/10.1127/njgpa/2016/0587

Becker, R.T., Feist, R., Flajs, G., House, M.R. \& Klapper, G., 1989. Frasnian-Famennian extinction events in the Devonian at Coumiac, southern France. Comptes Rendus de 1'Académie des Sciences Paris, Série II, 309, 259-266.

Bignon, A. \& Crônier, C., 2014. The systematics and phylogeny of the Devonian subfamily Asteropyginae (Trilobita: Phacopida). Journal of Systematic Palaeontology, 12, 637-668. https://doi.org/10.1080/1 4772019.2013.804008

Bignon, A. \& Crônier, C., 2015. Trilobite faunal dynamics on the Devonian continental shelves of the Ardenne Massif and Boulonnais (France, Belgium). Acta Palaeontologica Polonica, 60, 949-962. http://dx.doi.org/10.4202/app.00019.2013

Boulvain, F., 2007. Frasnian carbonate mounds from Belgium: sedimentology and palaeoceanography. In Álvaro, J.J., Aretz, M., Boulvain, F., Munnecke, A., Vachard, D. \& Vennin, E. (eds), Palaeozoic Reefs and Bioaccumulations: Climatic and Evolutionary Controls. Geological Society, London, Special Publications, 275, 125-142. https://doi.org/10.1144/GSL.SP.2007.275.01.09

Boulvain, F. \& Coen-Aubert, M., 1992. La carrière de marbre rouge de Beauchâteau: aperçu paléontologique, stratigraphique et sédimentologique. Annales de la Société Géologique de Belgique, 115, 19-22.

Boulvain, F., Bultynck, P., Coen, M., Coen-Aubert, M., Lacroix, D., Laloux, M., Casier, J.-G., Dejonghe, L., Dumoulin, V., Ghysel, P., Godefroid, J., Helsen, S., Mouravieff, N.A., Sartenaer, P., Tourneur, F. \& Vanguestaine, M., 1999. Les formations du Frasnien de la Belgique. Memoirs of the Geological Survey of Belgium, 44, 1-126.

Boulvain, F., de Ridder, C., Mamet, B., Préat, A. \& Gillan, D., 2001. Iron microbial communities in Belgian Frasnian carbonate mounds. Facies, 44, 47-59. https://doi.org/10.1007/BF02668166

Boulvain, F., Demany, B. \& Coen-Aubert, M., 2005. Frasnian carbonate build-ups of Southern Belgium: the Arche and Lion members interpreted as atolls. Geologica Belgica, 8, 69-89.

Boulvain, F., Coen-Aubert, M., Da Silva, A.-C., Kershaw, S., Tourneur, F., Denayer, J., Mottequin, B. \& Poty, E., 2011. 11th International Symposium on Fossil Cnidaria and Porifera. Liège 2011. Field Trip 1: Givetian and Frasnian of Southern Belgium. Kölner Forum Geologie und Paläontologie, 20, 5-49.

Bultynck, P. \& Hollevoet, C., 1999. The Eifelian-Givetian boundary and Struve's Middle Devonian Great Gap in the Couvin area (Ardennes, southern Belgium). Senckenbergiana lethaea, 79, 3-11. https://doi. org/10.1007/BF03043209 Bultynck, P., Helsen, S. \& Hayduckiewich, J., 1998. Conodont succession and biofacies in upper Frasnian formations (Devonian) from the southern and central parts of the Dinant Synclinorium (Belgium) - (Timing of facies shifting and correlation with late Frasnian events). Bulletin de l'Institut royal des Sciences naturelles de Belgique, Sciences de la Terre, 68, 25-75. 
Casier, J.-G., 2017. Ecology of Devonian ostracods: application to the Frasnian/Famennian boundary bioevent in the type region (Dinant Synclinorium, Belgium). Palaeobiodiversity and Palaeoenvironments, 97, 553-564. https://doi.org/10.1007/s12549-017-0278-z

Chlupáč, I., 1993 (imprint 1992). Trilobites from the Givetian and Frasnian of the Holy Cross Mountains. Acta Palaeontologica Polonica, 37, 395-406.

Chlupáč, I., 1994. Devonian trilobites - Evolution and events. Geobios, 27, 487-505. https://doi.org/10.1016/S0016-6995(09)90029-8

Coen, M. \& Coen-Aubert, M., 1971. L'Assise de Fromelennes aux bords sud et est du Bassin de Dinant et dans le Massif de la Vesdre. Annales de la Société Géologique de Belgique, 94, 5-20.

Coen-Aubert, M., 1992. La Carrière du Cimetière à Boussu-en-Fagne. Annales de la Société Géologique de Belgique, 115, 23-24.

Coen-Aubert, M., 2015. Revision of the genus Frechastraea Scrutton, 1968 (Rugosa) in the Upper Frasnian of Belgium. Geologica Belgica, $18,109-125$.

Crônier, C. \& Viersen, A.P. van, 2007. Trilobite palaeobiodiversity during the Devonian in the Ardennes Massif. Bulletin de la Société géologique de France, 178, 473-483. https://doi.org/10.2113/ gssgfbull.178.6.473

Da Silva, A.-C. \& Boulvain, F., 2004. From palaeosols to carbonate mounds: facies and environments of the middle Frasnian platform in Belgium. Geological Quarterly, 48, 253-266.

Da Silva, A.-C., Yans, J. \& Boulvain, F., 2010. Early-middle Frasnian (early Late Devonian) sedimentology and magnetic susceptibility of the Ardennes area (Belgium): identification of severe and rapid sealevel fluctuations. Geologica Belgica, 13, 319-332.

Delmer, A., 2004. Tectonique du front varisque en Hainaut et dans le Namurois. Memoirs of the Geological Survey of Belgium, 50, 1-61.

Dopieralska, J., Belka, Z. \& Walczak, A., 2016. Nd isotope composition of conodonts: An accurate proxy of sea-level fluctuations. Gondwana Research, 34, 284-295. https://doi.org/10.1016/j.gr.2015.02.022

Dormal, V., 1888. Contribution à l'étude du Système Dévonien dans le bassin de Namur. Annales de la Société Géologique de Belgique, 15, 88-111.

Feist, R., 1974. Devonische Scutelluidae (Trilobitae) aus der östlichen Montagne Noire (Südfrankreich). Palaeontographica (A), 147, 70114.

Feist, R., 1991. The Late Devonian trilobite crises. Historical Biology, 5, 197-214. https://doi.org/10.1080/10292389109380401

Feist, R., 1995. Effect of paedomorphosis in eye reduction on patterns of evolution and extinction in trilobites. In McNamara, K.J. (ed.) Evolutionary Changes and Heterochrony. John Wiley \& Sons, Chichester, 225-244.

Feist, R., 2002. Trilobites from the latest Frasnian Kellwasser Crisis in North Africa (Mrirt, central Moroccan Meseta). Acta Palaeontologica Polonica, 47, 203-210.

Feist, R., 2003. Biostratigraphy of Devonian tropidocoryphid trilobites from the Montagne Noire (southern France). Bulletin of Geosciences, $78,431-446$.

Feist, R. \& Schindler, E., 1994. Trilobites during the Frasnian Kellwasser Crisis in European Late Devonian cephalopod limestones. Courier Forschungsinstitut Senckenberg, 169, 195-223.

Fernández, L.P., Fernández-Martínez, E., García-Ramos, J.C., MéndezBedia, I. \& Soto, F., 1997. A sequential approach to the study of reefal facies in the Candás and Portilla Formations (Middle Devonian) of the Cantabrian Zone (NW Spain). Boletin Real Sociedad Española Historia Natural (Sección Geológica), 92, 23-33.

Gandl, J., 1972. Die Acastavinae und Asteropyginae (Trilobita) Keltiberiens (NE-Spanien). Abhandlungen der Senckenbergischen Naturforschenden Gesellschaft, 530, 1-183.

Gouwy, S. \& Bultynck, P., 2000. Graphic correlation of Frasnian sections (Upper Devonian) in the Ardennes, Belgium. Bulletin de l'Institut royal des Sciences naturelles de Belgique, Sciences de la Terre, 70, 25-52.

Gouwy, S. \& Bultynck, P., 2003. Conodont based graphic correlation of the Middle Devonian formations of the Ardenne (Belgium): implications for stratigraphy and construction of a regional composite. Revista Española de Micropaleontología, 35, 315-344.

Haas, W. \& Mensink, H., 1970. Asteropyginae aus Afghanistan (Trilobita). Abhandlungen der Mathematisch-Naturwissenschaftlichen Klasse, 1969, 1-60.

Helsen, S. \& Bultynck, P., 1992. Conodonts and megafauna from two sections at Nismes and Mariembourg (Frasnian of the southern flank of the Dinant Synclinorium, Belgium). Annales de la Société Géologique de Belgique, 115, 145-157.

House, M.R., 1985. Correlation of mid-Palaeozoic ammonoid evolutionary events with global sedimentary perturbations. Nature, 313, 17-22. https://doi.org/10.1038/313017a0
Humblet, M. \& Boulvain, F., 2000. Sedimentology of the Bieumont Member: influence of the Lion Member carbonate mounds (Frasnian, Belgium) on their sedimentary environment. Geologica Belgica, 3, 97-118.

Johnson, J.G., Klapper, G. \& Sandberg, C.A., 1985. Devonian eustatic fluctuations in Euramerica. Geological Society of America Bulletin, 96, 567-587. https://doi.org/10.1130/0016-7606(1985)96<567:DEFI $\mathrm{E}>2.0 . \mathrm{CO} ; 2$

Königshof, P., Helling, S., Hartenfels, S., Vleeschouwer, D. De, Schreiber, G., Becker, R.T. \& Brett, C.E., 2016. Eifel Synclines - an overview and Emsian to Frasnian section descriptions. Münstersche Forschungen zur Geologie und Paläontologie, 108, 36-45.

Kowalski, H., 1990. Trilobiten aus dem Devon der Eifel. Aufschluss, Sonderband, 33, 11-63.

Lieberman, B.S. \& Kloc, G.J., 1997. Evolutionary and biogeographic patterns in the Asteropyginae (Trilobita, Devonian) Delo, 1935. Bulletin of the American Museum of Natural History, 232, 1-127.

Loevezijn, G.B.S. van, 1988. Upper Devonian to lowermost Carboniferous concretion types and their stratigraphic significance (Cantabrian Mountains, N Spain). Trabajos de Geología, Universidad de Oviedo, $17,57-66$.

Lombard, A., 1952. Sédimentologie et évolution des lithofacies dévoniens du bord Nord du synclinal de Namur. Bulletin de la Société belge de Géologie, de Paléontologie et d'Hydrologie, 61, 44-82.

Magrean, B. \& Taghon, P., 2014. Trilobiten aus dem Mitteldevon der Ardennen. Teil 4: Phacopiden. Fossilien, 31/5, 24-29.

Maillieux, E., 1913. Quelques mots sur les récifs frasniens de la plaine des Fagnes, entre Nismes et Chimay. Bulletin de la Société belge de Géologie, de Paléontologie et d'Hydrologie, 27, 113-126.

Maillieux, E., 1927. Sur les trilobites du Frasnien de la Belgique. Bulletin de la Société belge de Géologie, de Paléontologie et d'Hydrologie, $37,77-87$.

Maillieux, E., 1936. La faune des schistes de Matagne (Frasnien supérieur). Mémoires du Musée royal d'Histoire naturelle de Belgique, 77, 1-74.

Maillieux, E., 1940. Contribution à la connaissance du Frasnien moyen (Assise de Frasnes) de la Belgique. Bulletin du Musée royal d'Histoire naturelle de Belgique, 16/14, 1-44.

Malaise, C., 1879. Description de gites fossilifères devoniens et d'affleurements du terrain Crétacé. Ministère de l'Intérieur. Commission de la carte géologique de la Belgique. F. Hayez, Bruxelles, 69 p.

McKellar, R.C. \& Chatterton, B.D.E., 2009. Early and Middle Devonian Phacopidae (Trilobita) of southern Morocco. Palaeontographica Canadiana, 28, 1-109.

McNamara, K.J. \& Feist, R., 2016. The effect of environmental changes on the evolution and extinction of Late Devonian trilobites from the northern Canning Basin, Western Australia. In Becker, R.T., Königshof, P. \& Brett, C.E. (eds), Devonian Climate, Sea Level and Evolutionary Events. Geological Society, London, Special Publications, 423, 251-271. https://doi.org/10.1144/SP423.5

Morzadec, P., 1983. Trilobites du Dévonien (Emsien-Famennien) de la Rade de Brest (Massif Armoricain). Palaeontographica (A), 181, 103-184.

Morzadec, P., 1992. Evolution des Asteropyginae (Trilobita) et variations eustatiques au Dévonien. Lethaia, 25, 85-96. https://doi. org/10.1111/j.1502-3931.1992.tb01793.x

Mottequin, B., 2005. Revision of the brachiopod Cyrtina rigauxi Maillieux, 1909 and description of a new ambocoeliid genus (Dionacoelia n. gen.) from the Frasnian of southern Belgium. Bulletin de 1'Institut royal des Sciences naturelles de Belgique, 75, $53-66$.

Mottequin, B., 2008a. Late Middle to Late Frasnian Atrypida, Pentamerida, and Terebratulida (Brachiopoda) from the NamurDinant Basin (Belgium). Geobios, 41, 491-513. https://doi org/10.1016/j.geobios.2007.10.008

Mottequin, B., 2008b. New observations on the Upper Devonian brachiopods from the Namur-Dinant Basin (Belgium). Geodiversitas, 30, 455-537.

Mottequin, B. \& Poty, E., 2015. Kellwasser horizons, sea-level changes and brachiopod-coral crises during the late Frasnian in the Namu - Dinant Basin (southern Belgium): a synopsis. In Becker, R.T. Königshof, P. \& Brett, C.E. (eds), Devonian Climate, Sea Level and Evolutionary Events. Geological Society, London, Special Publications, 423, 235-250. https://doi.org/10.1144/SP423.6

Owens, R.M., 1994. Pseudoextinctions in late Devonian proetide trilobites. Historical Biology, 9, 207-221. https://doi. org/10.1080/10292389409380498 Poty, E. \& Chevalier, E., 2007. Late Frasnian phillipsastreid biostromes in Belgium. In Álvaro, J.J., Aretz, M., Boulvain, F., Munnecke, A., Vachard, D. \& Vennin, E. (eds), Palaeozoic Reefs and Bioaccumulations: Climatic and Evolutionary Controls. Geological Society, London, Special Publications, 275, 143-161. https://doi.org/10.1144/GSL.SP.2007.275.01.10 
Racki, G., 2005. Toward understanding Late Devonian global events: few answers, many questions. In Over, D.J., Morrow, J.R. \& Wignall, P.B. (eds), Understanding Late Devonian and Permian-Triassic Biotic and Climatic Events: Towards an Integrated Approach. Elsevier, Amsterdam, 5-36.

Racki, G. \& Bultynck, P., 1993. Conodont biostratigraphy of the Middle to Upper Devonian boundary beds in the Kielce area of the Holy Cross Mts. Acta Geologica Polonica, 43, 1-25.

Richter, R., 1912. Beiträge zur Kenntnis devonischer Trilobiten. Erster Beitrag. Die Gattung Dechenella und einige verwandte Formen. Abhandlungen der Senckenbergischen Naturforschenden Gesellschaft, 31, 239-340.

Richter, R. \& Richter, E., 1926. Die Trilobiten des Oberdevons. Beiträge zur Kenntnis devonischer Trilobiten. IV. Abhandlungen der Preußischen Geologischen Landesanstalt, Neue Folge, 99, 1-314.

Sandberg, C.A., Morrow, J.R. \& Ziegler, W., 2002. Late Devonian sea-level changes, catastrophic events, and mass extinctions. In Koeberl, C. \& MacLeod, K.G. (eds), Catastrophic Events and Mass Extinctions: Impacts and Beyond. Geological Society of America Special Paper, 356, 473-487. https://doi.org/10.1130/0-8137-23566.473

Smeenk, Z., 1983. Devonian trilobites of the southern Cantabrian Mountains (northern Spain) with a systematic description of the Asteropyginae. Leidse Geologische Mededelingen, 52, 383-511.

Struve, W., 1982. The great gap in the record of marine Middle Devonian. In Ziegler, W. \& Werner, R. (eds), On Devonian Stratigraphy and Palaeontology of the Ardenno-Rhenish Mountains and related Devonian Matters. Courier Forschungsinstitut Senckenberg, 55, 433447.

Struve, W., 1992. Neues zur Stratigraphie und Fauna des rhenotypen Mittel-Devon. Senckenbergiana lethaea, 71, 503-624.

Trenkner, W., 1867. Paläontologische Novitäten vom Nordwestlichen Harze. I. Iberger Kalk und Kohlengebirge von Grund. Abhandlungen der Naturforschenden Gesellschaft zu Halle, 10, 123-182.

Vanherle, W., 2012. Het Frasniaan in het zuiden van België (Deel XIXa) Carrière du Cimetière te Boussu-en-Fagne. Inleiding en Brachiopoda. Hona, 47/3, 19-36.

Vanherle, W., 2013. Het Frasniaan in het zuiden van België (Deel XIXb) - Carrière du Cimetière te Boussu-en-Fagne. Koralen, Conularia, Bryozoa, Bivalven, Gastropoden, Tentaculieten, Crinoiden, Trilobieten, Receptaculieten en Problematica. Hona, 48/2, 28-44.

Viersen, A.P. van, 2007. Preliminary report of trilobites from the Hanonet Formation (Eifelian - Givetian transition), southern border of the Dinant Synclinorium, Belgium. Bulletin de l'Institut royal des Sciences naturelles de Belgique, Sciences de la Terre, 77, 15-29.

Viersen, A.P. van, 2015. Trilobites du Dévonien des Ardennes (zone rhéno-hercynienne): biostratigraphie, évolution et événements. Fossiles, Revue française de Paléontologie, 11, 5-24.

Viersen, A.P. van \& Bignon, A., 2011. Late Devonian (Frasnian) asteropygine trilobites from the Frasnes area, southern border of Dinant synclinorium, Belgium. Geologica Belgica, 14, 109-128.

Viersen, A.P. van \& Holland, D., 2016. Morphological trends and new species of Cyphaspis (Trilobita, Otarioninae) in the Devonian of Morocco, Turkey, Germany and Belgium. Geologica Belgica, 19, 251-271.

Viersen, A.P. van \& Prescher, H., 2007. Note on Cyphaspis Burmeister 1843 (Trilobita, Aulacopleuridae), with a review of several species mainly from the Devonian of Belgium and Germany. Senckenbergiana lethaea, 87, 157-170. https://doi.org/10.1007/BF03043912

Viersen, A.P. van \& Prescher, H., 2010. Taxonomy and biostratigraphy of some proetid trilobites in the Middle Devonian of the Ardennes and Eifel (Rhenohercynian Zone). Bulletin de 1'Institut royal des Sciences naturelles de Belgique, Sciences de la Terre, 80, 5-45.

Viersen, A.P. van \& Prescher, H., 2011. Two new species of scutelluid trilobites formerly known as Scutellum costatum from Frasnian bioherms in Belgium. Bulletin de l'Institut Royal des Sciences Naturelles de Belgique, Sciences de la Terre, 81, 55-61.

Viersen, A.P. van, Rossum, A. van \& Prescher, H., 2012. New data on Astycoryphe, Dohmiella, Longiproetus and Quadratoproetus (Trilobita, Proetidae) from the Middle Devonian in the Ardennes, Belgium. Neues Jahrbuch für Geologie und Paläontologie, Abhandlungen, 264, 77-87. https://doi.org/10.1127/00777749/2012/0233

Viersen, A.P. van, Taghon, P. \& Magrean, B., 2017. The phacopid trilobites Austerops McKellar \& Chatterton, 2009, Hottonops gen. nov. and Loreleiops gen. nov. from the Devonian of the ArdennoRhenish Mountains. Neues Jahrbuch für Geologie und Paläontologie, Abhandlungen, 283, 53-68. https://doi.org/10.1127/njgpa/2017/0626

Walliser, O.H., Bultynck, P., Weddige, K., Becker, R.T. \& House, M.R., 1995. Definition of the Eifelian-Givetian Stage boundary. Episodes, $18,107-115$.

Manuscript received 28.10.2017, accepted in revised form 02.03.2018, available on line 31.05.2018. 